М.В. Поспелов, А.В. Иванова, Л.Н. Дмитриева, А.А. Зимирова, Е.А. Чумачкова, В.А. Сафронов, И. Г. Карнаухов, С. А. Щербакова, В. В. Кутырев

\title{
АНАЛИЗ ДИНАМИКИ ЭПИДЕМИЧЕСКОГО ПРОЦЕССА СОVID-19 В МИРЕ ЗА НЕДЕЛЮ С 03.07.2021 г. ПО 09.07.2021 г.
}

ФКУЗ Российский научно-исследовательский противочумный институт «Микроб» Роспотребнадзора, Саратов, Российская Федерация

В обзоре представлен анализ эпидемиологической ситуации в странах мира по COVID19, за неделю с 03.07.2021 г. по 09.07.2021 г.

Анализ проведен на основании данных следующих ресурсов:

1. www.worldometers.info/coronavirus/

2. tass.ru/pandemiya-covid-19

3. www.skyscanner.ru/travel-restrictions

4. reopen.europa.eu/en/map/LVA/7001

5. intelyse.com/coronavirus-travel-restrictions/

6. gisanddata.maps.arcgis.com/apps/dashboards/bda7594740fd40299423467b48e9ecf6

Всего в мире зарегистрировано 185546660 случаев заболевания (24254 на 1 млн.); прирост за неделю составил 2927889 случаев (382,7 на 1 млн. населения) 1,6\%; 4010615 летальных исходов (524,2 на 1 млн. населения); прирост за неделю составил 54873 случая (7,2 на 1 млн. населения) - 1,4\%. За последнюю неделю показатель прироста новых случаев увеличился с 1,5\% до 1,6\%. Недельный прирост числа летальных исходов за последнюю неделю не изменился $-1,4 \%$. За последнюю неделю в мире каждый день число новых случаев увеличивалось на $300-500$ тысяч.

В общей структуре заболеваемости за неделю наибольшая доля новых случаев приходится на Американский регион (32,3\%, показатель уменьшился). Доля Юго-Восточной Азии изменилась мало (23,1\%). Доля случаев в Европейском регионе продемонстрировала незначительный рост в сравнении с прошлой 
неделей и составила 22,4\%. Доля Восточно-Средиземноморского региона увеличилась (10\%). Доля Африканского региона мало изменилась в сравнении с предыдущей неделей - 7,4\%. Наименьший удельный вес новых случаев заболевания приходится на страны Западно-Тихоокеанского региона $-4,9 \%$.

В Американском регионе - снижение числа новых случаев на 6\%. По числу еженедельно выявляемых случаев доминируют Бразилия, Аргентина и Колумбия (67,3\% от всех новых случаев в регионе). Наибольшее число заболевших в регионе на 1 млн населения за последнюю неделю зарегистрировано в Колумбии (3746) и Аргентине (2703). Наибольшее число случаев за неделю регистрируется в Бразилии (340458).

В Европейском регионе отмечен рост числа новых случаев на 35,8\%. Наибольший рост уровня заболеваемости - в Нидерландах, Греции и на Кипре. Наибольшее число инфицированных на 1 млн - на Кипре (5992) и в Великобритании (2929). Доля выявленных случаев в странах СНГ от всех зарегистрированных в Европейском регионе составила $32,5 \%$.

В Западно-Тихоокеанском регионе - рост числа зарегистрированных за неделю на $12,7 \%$ в сравнении с прошлой неделей. Наибольший рост уровня заболеваемости - во Вьетнаме. На две страны - Филиппины и Малайзию приходится $61,5 \%$ от всех выявленных случаев за последнюю неделю. Наибольшее число новых случаев на 1 млн населения за неделю - в Монголии (4853) и на Фиджи (4283).

В Восточно-Средиземноморском регионе - увеличение числа новых случаев заболевания на $22,6 \%$ в сравнении с прошлой неделей. Наибольший рост уровня заболеваемости - в Ливии и Ливане. На Иран приходится 37,3\% от всех случаев за последнюю неделю. Наибольшее число инфицированных на 1 млн населения за последнюю неделю - в Тунисе (3954), Кувейте (2953), Омане (2735).

В Юго-Восточной Азии - рост числа новых случаев на 12,2\%. Наибольший рост уровня заболеваемости - в Мьянме, Индонезии и Бангладеш. На Индию 
приходится 44,6\% от всех выявленных за неделю случаев. Наибольшее число заболевших на 1 млн населения за последнюю неделю зарегистрировано на Мальдивах (1668) и в Индонезии (804).

В Африканском регионе - увеличение числа новых случаев заболевания на $12 \%$ в сравнении с прошлой неделей. Наибольший рост уровня заболеваемости в Эсватини, Сенегале и Мозамбике. На ЮАР приходится 82,5\% от всех выявленных за неделю случаев. Наибольшее число заболевших на 1 млн населения за последнюю неделю - на Сейшелах (11225) и в Намибии (3925). 


\section{Справка об анализе динамики эпидемического процесса COVID-19 в мире}

за неделю с 03.07.2021 г. по 09.07.2021 г.

- Всего в мире зарегистрировано 185546660 случаев заболевания (24254 на 1 млн. населения); прирост за неделю составил 2927889 случаев (382,7 на 1 млн. населения) $-1,6 \%$.

- Всего в мире зарегистрировано 4010615 летальных исходов (524,2 на 1 млн. населения); прирост за неделю составил 54873 случая (7,2 на 1 млн. населения) $-1,4 \%$.

За неделю с 3 по 9 июля 2021 г. показатель прироста новых случаев в сравнении с неделей с 26 июня по 2 июля 2021 г. увеличился на 0,1\% и составил $1,6 \%$ (рисунок 1; таблица 1). Недельный прирост числа летальных исходов за анализируемую неделю не изменился в сравнениии с прошлой неделей $-1,4 \%$.

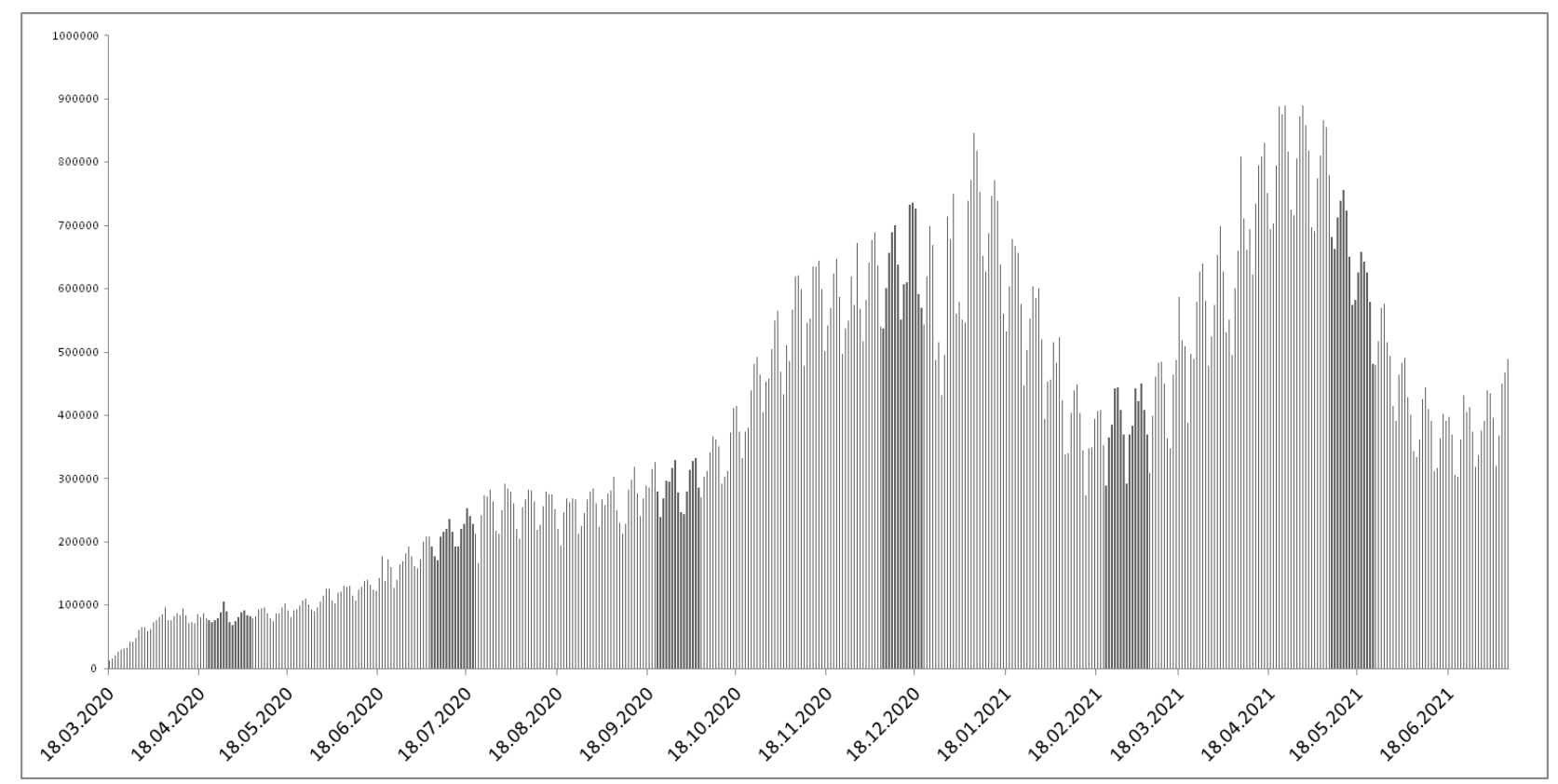

Рисунок 1 - Ежедневный прирост подтвержденных случаев в мире 


\begin{tabular}{|c|c|c|c|c|c|}
\hline Неделя & $\begin{array}{r}\text { Недель } \\
\text { ный прирост } \\
\text { (случаев) }\end{array}$ & $\begin{array}{l}\text { Недель } \\
\text { ный прирост } \\
(\%)\end{array}$ & Неделя & $\begin{array}{c}\text { Недел } \\
\text { ьный } \\
\text { прирост } \\
\text { (случаев) }\end{array}$ & $\begin{array}{c}\text { Недель } \\
\text { ный } \\
\text { прирост }(\%)\end{array}$ \\
\hline $\begin{array}{l}09-15 \\
\text { января }\end{array}$ & $\begin{array}{l}5093 \\
667\end{array}$ & 5,8 & $\begin{array}{l}10-16 \\
\text { апреля }\end{array}$ & $\begin{array}{l}5061 \\
518\end{array}$ & 3,8 \\
\hline $\begin{array}{l}16-22 \\
\text { января }\end{array}$ & $\begin{array}{l}4418 \\
138\end{array}$ & 4,7 & $\begin{array}{l}17-23 \\
\text { апреля }\end{array}$ & $\begin{array}{c}5540 \\
022\end{array}$ & 4,0 \\
\hline $\begin{array}{l}23 \text { - } 29 \\
\text { января }\end{array}$ & $\begin{array}{l}3928 \\
311\end{array}$ & 4,0 & $\begin{array}{l}24-30 \\
\text { апреля }\end{array}$ & $\begin{array}{l}5730 \\
784\end{array}$ & 4,0 \\
\hline $\begin{array}{c}30 \text { января } \\
-5 \text { февраля }\end{array}$ & $\begin{array}{l}3425 \\
183\end{array}$ & 3,4 & $\begin{array}{l}01-07 \\
\text { мая }\end{array}$ & $\begin{array}{c}5522 \\
787\end{array}$ & 3,7 \\
\hline $\begin{array}{c}06-12 \\
\text { февраля }\end{array}$ & $\begin{array}{l}2922 \\
707\end{array}$ & 2,8 & $\begin{array}{l}08 \text { - } 14 \\
\text { мая }\end{array}$ & $\begin{array}{l}5190 \\
039\end{array}$ & 3,3 \\
\hline $\begin{array}{c}13-19 \\
\text { февраля }\end{array}$ & $\begin{array}{l}2521 \\
410\end{array}$ & 2,3 & $\begin{array}{l}15-21 \\
\text { мая }\end{array}$ & $\begin{array}{l}4444 \\
155\end{array}$ & 2,7 \\
\hline $\begin{array}{c}20-26 \\
\text { февраля }\end{array}$ & $\begin{array}{l}2687 \\
157\end{array}$ & 2,4 & $\begin{array}{l}22-28 \\
\text { мая }\end{array}$ & $\begin{array}{l}3514 \\
812 \\
\end{array}$ & 2,1 \\
\hline $\begin{array}{c}27 \\
\text { февраля - } 05 \\
\text { марта }\end{array}$ & $\begin{array}{l}2614 \\
266\end{array}$ & 2,3 & $\begin{array}{c}29 \text { мая - } \\
04 \text { июня }\end{array}$ & $\begin{array}{l}3254 \\
304\end{array}$ & 1,9 \\
\hline $\begin{array}{l}06-12 \\
\text { марта }\end{array}$ & $\begin{array}{l}2881 \\
671 \\
\end{array}$ & 2,5 & $\begin{array}{l}05-11 \\
\text { июня }\end{array}$ & $\begin{array}{l}2745 \\
583 \\
\end{array}$ & 1,6 \\
\hline $\begin{array}{l}13-19 \\
\text { марта }\end{array}$ & $\begin{array}{l}3255 \\
839\end{array}$ & 2,7 & $\begin{array}{l}12-18 \\
\text { июня }\end{array}$ & $\begin{array}{l}2587 \\
203\end{array}$ & 1,5 \\
\hline $\begin{array}{l}20-26 \\
\text { марта }\end{array}$ & $\begin{array}{l}3610 \\
517\end{array}$ & 2,9 & $\begin{array}{l}19-25 \\
\text { июня }\end{array}$ & $\begin{array}{r}2 \\
576278\end{array}$ & 1,5 \\
\hline $\begin{array}{r}27 \text { марта } \\
-02 \text { апреля } \\
\end{array}$ & $\begin{array}{l}4154 \\
907\end{array}$ & 3,3 & $\begin{array}{c}26 \text { июня } \\
-2 \text { июля } \\
\end{array}$ & $\begin{array}{l}2650 \\
167 \\
\end{array}$ & 1,5 \\
\hline $\begin{array}{l}03-09 \\
\text { апреля }\end{array}$ & $\begin{array}{l}4286 \\
980\end{array}$ & 3,3 & $\begin{array}{l}3 \text { - } 9 \\
\text { июля }\end{array}$ & $\begin{array}{l}2927 \\
889\end{array}$ & 1,6 \\
\hline
\end{tabular}




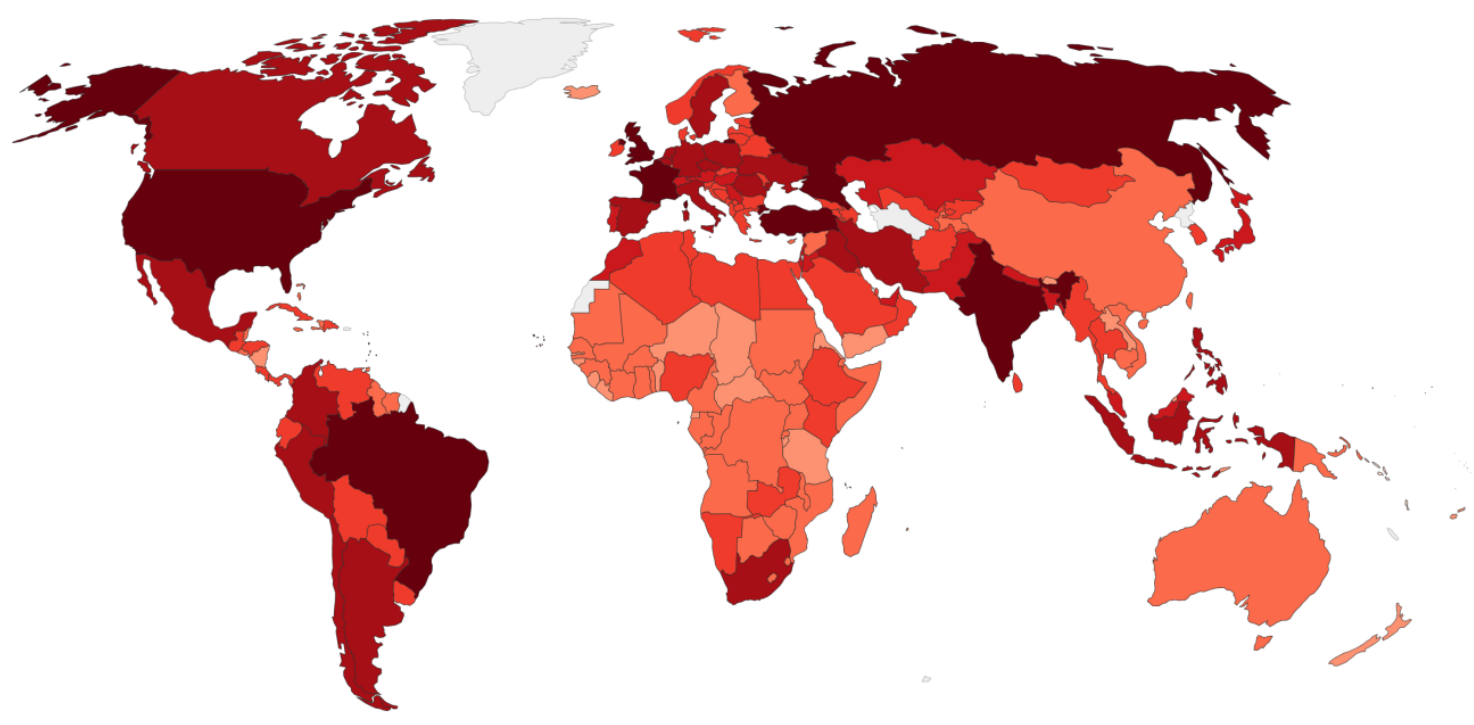

No data

none 1

50

100

10,000

$100,000 \quad 500,000 \quad 1$ million 5 million $>10$ million

Рисунок 2 - Количество зарегистрированных случаев с 03.07.2021 г. по 09.07.2021 г.

За последнюю неделю в мире каждый день число новых случаев увеличивалось на 300 - 500 тысяч (таблица 2). 
Таблица 2 - Количество дней, в течение которого зафиксирован прирост в 1 млн новых случаев

\begin{tabular}{|c|c|c|c|c|c|}
\hline $\begin{array}{l}\text { Прирос } \\
\text { T }\end{array}$ & $\begin{array}{c}\text { Количес } \\
\text { тво дней, } \\
\text { понадобивши } \\
\text { хся для } \\
\text { преодоления } \\
\text { отметки }\end{array}$ & $\begin{array}{l}\text { Прирос } \\
\text { T }\end{array}$ & $\begin{array}{c}\text { Кол } \\
\text { ичество } \\
\text { дней, } \\
\text { понадоби } \\
\text { вшихся } \\
\text { для } \\
\text { преодоле } \\
\text { ния } \\
\text { отметки }\end{array}$ & Прирост & $\begin{array}{c}\text { Количес } \\
\text { тво дней, } \\
\text { понадобивши } \\
\text { хся для } \\
\text { преодоления } \\
\text { отметки }\end{array}$ \\
\hline $\begin{array}{l}\text { от } 0 \text { до } \\
1 \text { млн. }\end{array}$ & $\begin{array}{l}\sim 100 \\
\text { дней }\end{array}$ & $\begin{array}{l}\text { от } 62 \text { до } \\
63 \text { млН }\end{array}$ & ${ }_{\text {дня }}^{2}$ & $\begin{array}{l}\text { от } 124 \text { до } \\
125 \text { млн }\end{array}$ & 2 дня \\
\hline $\begin{array}{l}\text { от } 1 \text { до } \\
2 \text { млн. }\end{array}$ & 12 дней & $\begin{array}{l}\text { от } 63 \text { до } \\
64 \text { млн }\end{array}$ & ${ }^{2}$ & $\begin{array}{l}\text { от } 125 \text { до } \\
126 \text { млн }\end{array}$ & 2 дня \\
\hline $\begin{array}{l}\text { от } 2 \text { до } \\
3 \text { млн. }\end{array}$ & 13 дней & $\begin{array}{l}\text { от } 64 \text { до } \\
65 \text { млн }\end{array}$ & дня & $\begin{array}{l}\text { от } 126 \text { до } \\
127 \mathrm{Mлн}\end{array}$ & 1 день \\
\hline $\begin{array}{l}\text { от } 3 \text { до } \\
4 \text { млн. }\end{array}$ & 12 дней & $\begin{array}{l}\text { от } 65 \text { до } \\
66 \text { млн }\end{array}$ & дня & $\begin{array}{l}\text { от } 127 \text { до } \\
128 \text { млн }\end{array}$ & 2 дня \\
\hline $\begin{array}{l}\text { от } 4 \text { до } \\
5 \text { млн. }\end{array}$ & 11 дней & $\begin{array}{l}\text { от } 66 \text { до } \\
67 \text { млН }\end{array}$ & ${ }_{\text {дня }}^{2}$ & $\begin{array}{l}\text { от } 128 \text { до } \\
129 \text { млн }\end{array}$ & 2 дня \\
\hline $\begin{array}{l}\text { от } 5 \text { до } \\
6 \text { млн. }\end{array}$ & 10 дней & $\begin{array}{l}\text { от } 67 \text { до } \\
68 \text { млн }\end{array}$ & ${ }^{2}$ & $\begin{array}{l}\text { от } 129 \text { до } \\
130 \text { млн }\end{array}$ & 1 день \\
\hline $\begin{array}{l}\text { от } 6 \text { до } \\
7 \text { млн. }\end{array}$ & 8 дней & $\begin{array}{l}\text { от } 68 \text { до } \\
69 \text { млн }\end{array}$ & дня & $\begin{array}{l}\text { от } 130 \text { до } \\
131 \text { млн }\end{array}$ & 2 дня \\
\hline $\begin{array}{l}\text { от } 7 \text { до } \\
8 \text { млн. }\end{array}$ & 8 дней & $\begin{array}{l}\text { от } 69 \text { до } \\
70 \text { млН }\end{array}$ & $\begin{array}{c}1 \\
\text { день }\end{array}$ & $\begin{array}{l}\text { от } 131 \text { до } \\
132 \text { млн }\end{array}$ & 2 дня \\
\hline $\begin{array}{l}\text { от } 8 \text { до } \\
9 \text { млн. }\end{array}$ & 6 дней & $\begin{array}{l}\text { от } 70 \text { до } \\
71 \text { млн }\end{array}$ & ${ }_{\text {дня }}^{2}$ & $\begin{array}{l}\text { от } 132 \text { до } \\
133 \text { млн }\end{array}$ & 2 дня \\
\hline $\begin{array}{l}\text { от } 9 \text { до } \\
10 \text { млн. }\end{array}$ & 6 дней & $\begin{array}{l}\text { от } 71 \text { до } \\
72 \text { млн }\end{array}$ & день & $\begin{array}{l}\text { от } 133 \text { до } \\
134 \text { млн }\end{array}$ & 1 день \\
\hline $\begin{array}{r}\text { от } 10 \\
\text { до } 11 \mathrm{млн.}\end{array}$ & 5 дней & $\begin{array}{l}\text { от } 72 \text { до } \\
73 \text { млН }\end{array}$ & ${ }_{\text {дня }}^{2}$ & $\begin{array}{l}\text { от } 134 \text { до } \\
135 \text { млн }\end{array}$ & 1 день \\
\hline $\begin{array}{r}\text { от } 11 \\
\text { до } 12 \text { млн. }\end{array}$ & 5 дней & $\begin{array}{l}\text { от } 73 \text { до } \\
74 \text { млн }\end{array}$ & 1 & $\begin{array}{l}\text { от } 135 \text { до } \\
136 \text { млн }\end{array}$ & 2 дня \\
\hline $\begin{array}{r}\text { от } 12 \\
\text { до } 13 \text { млн. }\end{array}$ & 5 дней & $\begin{array}{l}\text { от } 74 \text { до } \\
75 \text { млн }\end{array}$ & ${ }^{2}$ & $\begin{array}{l}\text { от } 136 \text { до } \\
137 \text { млн }\end{array}$ & 1 день \\
\hline $\begin{array}{r}\text { от } 13 \\
\text { до } 14 \text { млн. }\end{array}$ & 5 дней & $\begin{array}{l}\text { от } 75 \text { до } \\
76 \text { млн }\end{array}$ & 1 & $\begin{array}{l}\text { от } 137 \text { до } \\
138 \text { млн }\end{array}$ & 1 день \\
\hline $\begin{array}{r}\text { от } 14 \\
\text { до } 15 \text { млн. }\end{array}$ & 5 дней & $\begin{array}{l}\text { от } 76 \text { до } \\
77 \text { млн }\end{array}$ & ${ }_{\text {дня }}^{2}$ & $\begin{array}{c}\text { от } 138 \text { до } \\
139 \text { млн }\end{array}$ & 2 дня \\
\hline $\begin{array}{r}\text { от } 15 \\
\text { до } 16 \text { млн }\end{array}$ & 4 дня & $\begin{array}{l}\text { от } 77 \text { до } \\
78 \text { млн }\end{array}$ & 2 & $\begin{array}{l}\text { от } 139 \text { до } \\
140 \text { млн } \\
\end{array}$ & 1 день \\
\hline $\begin{array}{r}\text { от } 16 \\
\text { до } 17 \text { млн. }\end{array}$ & 4 дня & $\begin{array}{l}\text { от } 78 \text { до } \\
79 \text { млН }\end{array}$ & $\begin{array}{r}1 \\
\text { день } \\
\end{array}$ & $\begin{array}{l}\text { от } 140 \text { до } \\
141 \text { млн }\end{array}$ & 1 день \\
\hline $\begin{array}{r}\text { от } 17 \\
\text { до } 18 \text { млн }\end{array}$ & 4 дня & $\begin{array}{l}\text { от } 79 \text { до } \\
80 \text { млн }\end{array}$ & ${ }^{2}$ & $\begin{array}{l}\text { от } 141 \text { до } \\
142 \text { млн }\end{array}$ & 2 дня \\
\hline $\begin{array}{r}\text { от } 18 \\
\text { до } 19 \text { млн. } \\
\end{array}$ & 4 дня & $\begin{array}{l}\text { от } 80 \text { до } \\
81 \text { млН }\end{array}$ & $\begin{array}{r}1 \\
\text { день }\end{array}$ & $\begin{array}{l}\text { от } 142 \text { до } \\
143 \text { млн }\end{array}$ & 1 день \\
\hline
\end{tabular}




\begin{tabular}{|c|c|c|c|c|c|}
\hline $\begin{array}{r}\text { от } 19 \\
\text { до } 20 \text { млн } \\
\end{array}$ & 4 дня & $\begin{array}{l}\text { от } 81 \text { до } \\
82 \text { млн }\end{array}$ & ${ }_{\text {дня }}^{2}$ & $\begin{array}{l}\text { от } 143 \text { до } \\
144 \text { млн }\end{array}$ & 1 день \\
\hline $\begin{array}{r}\text { от } 20 \\
\text { до } 21 \text { млн }\end{array}$ & 4 дня & $\begin{array}{l}\text { от } 82 \text { до } \\
83 \text { млн }\end{array}$ & $\begin{array}{c}1 \\
\text { день }\end{array}$ & $\begin{array}{l}\text { от } 144 \text { до } \\
145 \text { млн }\end{array}$ & 1 день \\
\hline $\begin{array}{r}\text { от } 21 \\
\text { до } 22 \text { млн }\end{array}$ & 4 дня & $\begin{array}{l}\text { от } 83 \text { до } \\
84 \text { мЛн }\end{array}$ & дня & $\begin{array}{l}\text { от } 145 \text { до } \\
146 \text { млН }\end{array}$ & 1 день \\
\hline $\begin{array}{r}\text { от } 22 \\
\text { до } 23 \text { млн }\end{array}$ & 4 дня & $\begin{array}{l}\text { от } 84 \text { до } \\
85 \text { млн }\end{array}$ & $\begin{array}{c}1 \\
\text { день }\end{array}$ & $\begin{array}{l}\text { от } 146 \text { до } \\
147 \text { мЛн }\end{array}$ & 2 дня \\
\hline $\begin{array}{r}\text { от } 23 \\
\text { до } 24 \text { млн }\end{array}$ & 4 дня & $\begin{array}{l}\text { от } 85 \text { до } \\
86 \text { млн }\end{array}$ & дня & $\begin{array}{l}\text { от } 147 \text { до } \\
148 \text { млн }\end{array}$ & 1 день \\
\hline $\begin{array}{r}\text { от } 24 \\
\text { до } 25 \mathrm{млн} \\
\end{array}$ & 4 дня & $\begin{array}{l}\text { от } 86 \text { до } \\
87 \text { мЛн }\end{array}$ & $\begin{array}{c}1 \\
\text { день }\end{array}$ & $\begin{array}{l}\text { от } 148 \text { до } \\
149 \text { млН }\end{array}$ & 1 день \\
\hline $\begin{array}{r}\text { от } 25 \\
\text { до } 26 \text { млн }\end{array}$ & 4 дня & $\begin{array}{l}\text { от } 87 \text { до } \\
88 \text { млН }\end{array}$ & $\begin{array}{c}1 \\
\text { день }\end{array}$ & $\begin{array}{l}\text { от } 149 \text { до } \\
150 \text { млн }\end{array}$ & 1 день \\
\hline $\begin{array}{r}\text { от } 26 \\
\text { до } 27 \text { млн }\end{array}$ & 4 дня & $\begin{array}{l}\text { от } 88 \text { до } \\
89 \text { мЛн }\end{array}$ & $\begin{array}{c}1 \\
\text { день }\end{array}$ & $\begin{array}{l}\text { от } 150 \text { до } \\
151 \text { млн }\end{array}$ & 1 день \\
\hline $\begin{array}{r}\text { от } 27 \\
\text { до } 28 \text { млн } \\
\end{array}$ & 4 дня & $\begin{array}{l}\text { от } 89 \text { до } \\
90 \text { млН }\end{array}$ & $\begin{array}{c}1 \\
\text { день } \\
\end{array}$ & $\begin{array}{l}\text { от } 151 \text { до } \\
152 \text { млн }\end{array}$ & 1 день \\
\hline $\begin{array}{r}\text { от } 28 \\
\text { до } 29 \text { млн }\end{array}$ & 4 дня & $\begin{array}{l}\text { от } 90 \text { до } \\
91 \text { млн }\end{array}$ & ${ }^{2}$ & $\begin{array}{c}\text { от } 152 \text { до } \\
153 \text { млн }\end{array}$ & 1 день \\
\hline $\begin{array}{r}\text { от } 29 \\
\text { до } 30 \text { млн }\end{array}$ & 4 дня & $\begin{array}{l}\text { от } 91 \text { до } \\
92 \text { млн }\end{array}$ & $\begin{array}{c}1 \\
\text { день }\end{array}$ & $\begin{array}{l}\text { от } 153 \text { до } \\
154 \text { млн }\end{array}$ & 2 дня \\
\hline $\begin{array}{r}\text { от } 30 \\
\text { до } 31 \text { млн }\end{array}$ & 4 дня & $\begin{array}{l}\text { от } 92 \text { до } \\
93 \text { млн }\end{array}$ & $\begin{array}{c}1 \\
\text { день }\end{array}$ & $\begin{array}{l}\text { от } 154 \text { до } \\
155 \text { млн }\end{array}$ & 1 день \\
\hline $\begin{array}{r}\text { от } 31 \\
\text { до } 32 \text { млн } \\
\end{array}$ & 4 дня & $\begin{array}{l}\text { от } 93 \text { до } \\
94 \mathrm{мЛн}\end{array}$ & $\begin{array}{c}1 \\
\text { день }\end{array}$ & $\begin{array}{l}\text { от } 155 \text { до } \\
156 \text { млн }\end{array}$ & 1 день \\
\hline $\begin{array}{r}\text { от } 32 \\
\text { до } 33 \text { млн }\end{array}$ & 4 дня & $\begin{array}{l}\text { от } 94 \text { до } \\
95 \text { млн }\end{array}$ & $\begin{array}{c}1 \\
\text { день }\end{array}$ & $\begin{array}{c}\text { от } 156 \text { до } \\
157 \text { млн }\end{array}$ & 1 день \\
\hline $\begin{array}{r}\text { от } 33 \\
\text { до } 34 \text { млн }\end{array}$ & 4 дня & $\begin{array}{l}\text { от } 95 \text { до } \\
96 \text { млн }\end{array}$ & ${ }^{2}$ & $\begin{array}{l}\text { от } 157 \text { до } \\
158 \text { млн }\end{array}$ & 2 дня \\
\hline $\begin{array}{r}\text { от } 34 \\
\text { до } 35 \mathrm{млн} \\
\end{array}$ & 4 дня & $\begin{array}{l}\text { от } 96 \text { до } \\
97 \text { млн }\end{array}$ & $\begin{array}{c}1 \\
\text { день }\end{array}$ & $\begin{array}{l}\text { от } 158 \text { до } \\
159 \text { млн }\end{array}$ & 1 день \\
\hline $\begin{array}{r}\text { от } 35 \\
\text { до } 36 \text { млн }\end{array}$ & 4 дня & $\begin{array}{l}\text { от } 97 \text { до } \\
98 \text { млн }\end{array}$ & $\begin{array}{c}1 \\
\text { день }\end{array}$ & $\begin{array}{l}\text { от } 159 \text { до } \\
160 \text { млн }\end{array}$ & 1 день \\
\hline $\begin{array}{r}\text { от } 36 \\
\text { до } 37 \text { млн }\end{array}$ & 4 дня & $\begin{array}{l}\text { от } 98 \text { до } \\
99 \text { млн }\end{array}$ & дня & $\begin{array}{l}\text { от } 160 \text { до } \\
161 \text { млн }\end{array}$ & 1 день \\
\hline $\begin{array}{r}\text { от } 37 \\
\text { до } 38 \text { млн }\end{array}$ & 4 дня & $\begin{array}{l}\text { от } 99 \text { до } \\
100 \mathrm{MЛн}\end{array}$ & ${ }_{\text {дня }}^{2}$ & $\begin{array}{l}\text { от } 161 \text { до } \\
162 \text { млн }\end{array}$ & 2 дня \\
\hline $\begin{array}{r}\text { от } 38 \\
\text { до } 39 \text { млн }\end{array}$ & 3 дня & $\begin{array}{r}\text { от } 100 \\
\text { до } 101 \mathrm{Mлн}\end{array}$ & дня & $\begin{array}{l}\text { от } 162 \text { до } \\
163 \text { млн }\end{array}$ & 2 дня \\
\hline $\begin{array}{r}\text { от } 39 \\
\text { до } 40 \text { млн }\end{array}$ & 3 дня & $\begin{array}{r}\text { от } 101 \\
\text { до } 102 \text { млн }\end{array}$ & $\begin{array}{c}1 \\
\text { день }\end{array}$ & $\begin{array}{l}\text { от } 163 \text { до } \\
164 \text { млн }\end{array}$ & 2 дня \\
\hline $\begin{array}{r}\text { от } 40 \\
\text { до } 41 \text { млн }\end{array}$ & 2 дня & $\begin{array}{r}\text { от } 102 \\
\text { до } 103 \mathrm{MлН}\end{array}$ & $\begin{array}{l}{ }^{3} \\
\text { дня }\end{array}$ & $\begin{array}{l}\text { от } 164 \text { до } \\
165 \mathrm{млН}\end{array}$ & 1 день \\
\hline $\begin{array}{r}\text { от } 41 \\
\text { до } 42 \text { млн } \\
\end{array}$ & 2 дня & $\begin{array}{r}\text { от } 103 \\
\text { до } 104 \mathrm{MлН} \\
\end{array}$ & дня & $\begin{array}{l}\text { от } 165 \text { до } \\
166 \text { млн }\end{array}$ & 2 дня \\
\hline $\begin{array}{r}\text { от } 42 \\
\text { до } 43 \text { млн }\end{array}$ & 3 дня & $\begin{array}{r}\text { от } 104 \\
\text { до } 105 \text { млн }\end{array}$ & дня & $\begin{array}{l}\text { от } 166 \text { до } \\
167 \text { млн }\end{array}$ & 2 дня \\
\hline $\begin{array}{r}\text { от } 43 \\
\text { до } 44 \text { млн } \\
\end{array}$ & 2 дня & $\begin{array}{r}\text { от } 105 \\
\text { до } 106 \text { млн } \\
\end{array}$ & ${ }_{\text {дня }}^{2}$ & $\begin{array}{l}\text { от } 167 \text { до } \\
168 \text { млн }\end{array}$ & 2 дня \\
\hline
\end{tabular}




\begin{tabular}{|c|c|c|c|c|c|}
\hline $\begin{array}{r}\text { от } 44 \\
\text { до } 45 \text { мЛН }\end{array}$ & 2 дня & $\begin{array}{r}\text { от } 106 \\
\text { до } 107 \text { млн }\end{array}$ & дня $^{3}$ & $\begin{array}{l}\text { от } 168 \text { до } \\
169 \text { млн }\end{array}$ & 2 дня \\
\hline $\begin{array}{r}\text { от } 45 \\
\text { до } 46 \text { млн }\end{array}$ & 2 дня & $\begin{array}{r}\text { от } 107 \\
\text { до } 108 \text { млн }\end{array}$ & дня & $\begin{array}{l}\text { от } 169 \text { до } \\
170 \text { млн }\end{array}$ & 2 дня \\
\hline $\begin{array}{r}\text { от } 46 \\
\text { до } 47 \text { млн }\end{array}$ & 2 дня & $\begin{array}{r}\text { от } 108 \\
\text { до } 109 \text { млн }\end{array}$ & $\begin{array}{l}3 \\
\text { дня }\end{array}$ & $\begin{array}{l}\text { от } 170 \text { до } \\
171 \mathrm{млн}\end{array}$ & 2 дня \\
\hline $\begin{array}{r}\text { от } 47 \\
\text { до } 48 \text { млн }\end{array}$ & 2 дня & $\begin{array}{r}\text { от } 109 \\
\text { до } 110 \text { млн }\end{array}$ & дня ${ }^{3}$ & $\begin{array}{l}\text { от } 171 \text { до } \\
172 \text { млн }\end{array}$ & 2 дня \\
\hline $\begin{array}{r}\text { от } 48 \\
\text { до } 49 \text { млн }\end{array}$ & 2 дня & $\begin{array}{r}\text { от } 110 \\
\text { до } 111 \text { млн }\end{array}$ & ${ }^{2}$ & $\begin{array}{l}\text { от } 172 \text { до } \\
173 \text { млн }\end{array}$ & 3 дня \\
\hline $\begin{array}{r}\text { от } 49 \\
\text { до } 50 \text { млн }\end{array}$ & 2 дня & $\begin{array}{r}\text { от } 111 \\
\text { до } 112 \text { млн }\end{array}$ & дня ${ }^{3}$ & $\begin{array}{l}\text { от } 173 \text { до } \\
174 \text { млн }\end{array}$ & 3 дня \\
\hline $\begin{array}{r}\text { от } 50 \\
\text { до } 51 \text { млн }\end{array}$ & 2 дня & $\begin{array}{r}\text { от } 112 \\
\text { до } 113 \mathrm{млн}\end{array}$ & $\begin{array}{l}3 \\
\text { дня }\end{array}$ & $\begin{array}{l}\text { от } 174 \text { до } \\
175 \text { млн }\end{array}$ & 2 дня \\
\hline $\begin{array}{r}\text { от } 51 \\
\text { до } 52 \text { млн }\end{array}$ & 2 дня & $\begin{array}{r}\text { от } 113 \\
\text { до } 114 \text { млн }\end{array}$ & дня & $\begin{array}{l}\text { от } 175 \text { до } \\
176 \text { млн }\end{array}$ & 3 дня \\
\hline $\begin{array}{r}\text { от } 52 \\
\text { до } 53 \text { млн }\end{array}$ & 2 дня & $\begin{array}{r}\text { от } 114 \\
\text { до } 115 \text { млн }\end{array}$ & дня ${ }^{3}$ & $\begin{array}{l}\text { от } 176 \text { до } \\
177 \text { млн }\end{array}$ & 3 дня \\
\hline $\begin{array}{r}\text { от } 53 \\
\text { до } 54 \text { млн }\end{array}$ & 2 дня & $\begin{array}{r}\text { от } 115 \\
\text { до } 116 \text { млн }\end{array}$ & дня ${ }^{3}$ & $\begin{array}{l}\text { от } 177 \text { до } \\
178 \text { млн }\end{array}$ & 2 дня \\
\hline $\begin{array}{r}\text { от } 54 \\
\text { до } 55 \text { млн }\end{array}$ & 2 дня & $\begin{array}{r}\text { от } 116 \\
\text { до } 117 \text { млн }\end{array}$ & ${ }_{\text {дня }}^{3}$ & $\begin{array}{l}\text { от } 178 \text { до } \\
179 \text { млн }\end{array}$ & 3 дня \\
\hline $\begin{array}{r}\text { от } 55 \\
\text { до } 56 \text { млн }\end{array}$ & 2 дня & $\begin{array}{r}\text { от } 117 \\
\text { до } 118 \text { млн }\end{array}$ & дня & $\begin{array}{l}\text { от } 179 \text { до } \\
180 \text { млн }\end{array}$ & 3 дня \\
\hline $\begin{array}{r}\text { от } 56 \\
\text { до } 57 \text { млн }\end{array}$ & 2 дня & $\begin{array}{r}\text { от } 118 \\
\text { до } 119 \text { млн }\end{array}$ & дня & $\begin{array}{l}\text { от } 180 \text { до } \\
181 \text { млн }\end{array}$ & 3 дня \\
\hline $\begin{array}{r}\text { от } 57 \\
\text { до } 58 \text { млн }\end{array}$ & 2 дня & $\begin{array}{r}\text { от } 119 \\
\text { до } 120 \text { млн }\end{array}$ & $\begin{array}{l}3 \\
\text { дня }\end{array}$ & $\begin{array}{l}\text { от } 181 \text { до } \\
182 \mathrm{млн}\end{array}$ & 3 дня \\
\hline $\begin{array}{r}\text { от } 58 \\
\text { до } 59 \text { млн }\end{array}$ & 2 дня & $\begin{array}{r}\text { от } 120 \\
\text { до } 121 \mathrm{млн}\end{array}$ & ${ }^{2}$ & $\begin{array}{l}\text { от } 182 \text { до } \\
183 \text { млн }\end{array}$ & 3 дня \\
\hline $\begin{array}{r}\text { от } 59 \\
\text { до } 60 \text { мЛн }\end{array}$ & 2 дня & $\begin{array}{r}\text { от } 121 \\
\text { до } 122 \text { млн }\end{array}$ & дня & $\begin{array}{l}\text { от } 183 \text { до } \\
184 \text { млн }\end{array}$ & 3 дня \\
\hline $\begin{array}{r}\text { от } 60 \\
\text { до } 61 \text { млн }\end{array}$ & 2 дня & $\begin{array}{r}\text { от } 122 \\
\text { до } 123 \text { млн }\end{array}$ & ${ }^{2}$ & $\begin{array}{l}\text { от } 184 \text { до } \\
185 \text { млн }\end{array}$ & 2 дня \\
\hline $\begin{array}{r}\text { от } 61 \\
\text { до } 62 \text { млн }\end{array}$ & 2 дня & $\begin{array}{r}\text { от } 123 \\
\text { до } 124 \text { млн }\end{array}$ & ${ }^{2}$ & & \\
\hline
\end{tabular}


В общей структуре заболеваемости за неделю с 3 по 9 июля 2021 г. наибольшая доля новых случаев по-прежнему приходится на Американский регион (32,3\%, показатель уменьшился). За анализируемый период доля ЮгоВосточной Азии изменилась мало (23,1\%). Доля случаев в Европейском регионе продемонстрировала рост в сравнении с прошлой неделей и составила $22,4 \%$. Доля Восточно-Средиземноморского региона вновь увеличилась в сравнении с предыдущей неделей (10\%). Доля Африканского региона мало изменилась в сравнении с предыдущей неделей - 7,4\%. Наименьший удельный вес новых случаев заболевания приходится на страны Западно-Тихоокеанского региона 4,9\% (рисунок 3; таблица 3).

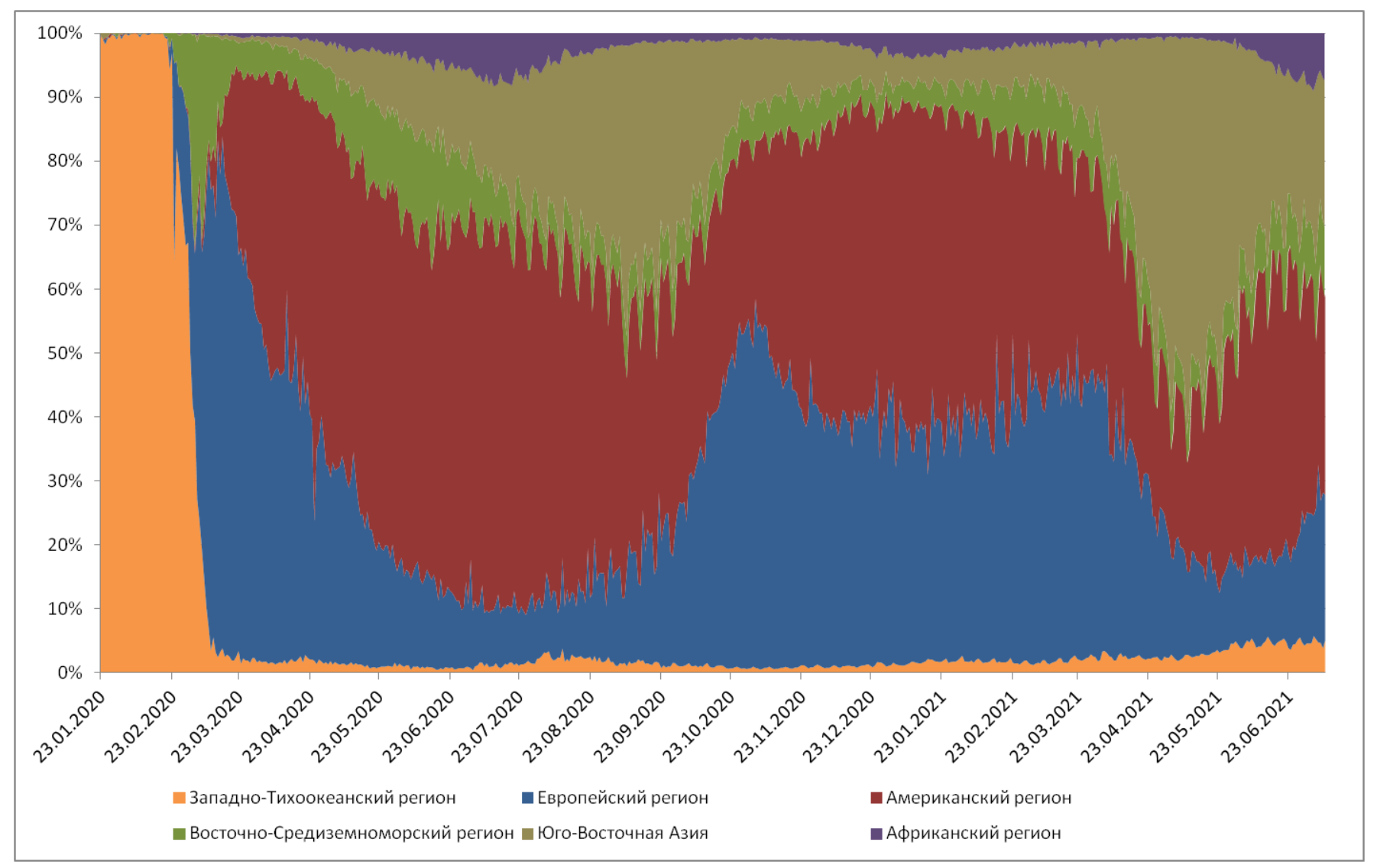

Рисунок 3 - Доля регионов мира в ежедневном приросте случаев заболевания 
Таблица 3 - Средняя доля региона от ежедневного прироста в мире

\begin{tabular}{|c|c|c|c|c|c|c|c|c|c|c|}
\hline \multicolumn{11}{|c|}{ Средняя доля региона от ежедневного прироста в мире, \% } \\
\hline $\begin{array}{c}\text { Регионы } \\
\text { ВО3 }\end{array}$ & $\begin{array}{c}\quad \mathrm{H} \\
\text { еделя } \\
01- \\
07 \\
\text { мая }\end{array}$ & $\begin{array}{c}\mathrm{H} \\
\text { еделя } \\
08- \\
14 \\
\text { мая }\end{array}$ & $\begin{array}{c}\quad \mathrm{H} \\
\text { еделя } \\
15- \\
21 \\
\text { мая }\end{array}$ & $\begin{array}{c}\text { H } \\
\text { еделя } \\
22- \\
28 \\
\text { мая }\end{array}$ & $\begin{array}{c}\text { H } \\
\text { еделя } \\
29 \\
\text { мая - } \\
04 \\
\text { июня } \\
\end{array}$ & $\begin{array}{c}\quad \mathrm{H} \\
\text { еделя } \\
05- \\
11 \\
\text { июня }\end{array}$ & $\begin{array}{c}\mathrm{H} \\
\text { еделя } \\
12- \\
18 \\
\text { июня }\end{array}$ & $\begin{array}{c}\mathrm{H} \\
\text { еделя } \\
19- \\
25 \\
\text { июня }\end{array}$ & $\begin{array}{c}\text { H } \\
\text { еделя } \\
26 \\
\text { июня } \\
-2 \\
\text { июля } \\
\end{array}$ & $\begin{array}{r}\text { H } \\
\text { еделя } \\
3-9 \\
\text { июля }\end{array}$ \\
\hline $\begin{array}{c}\text { Западно } \\
- \\
\text { Тихоокеанск } \\
\text { ий регион }\end{array}$ &, $3^{2}$ & $6^{2}$ & $9^{2}$ & $4^{3}$ & $4^{4}$ & $6^{4}$ &, $8^{4}$ & $6^{4}$ &, $8^{4}$ &, $9^{4}$ \\
\hline $\begin{array}{c}\text { Европе } \\
\text { йский регион }\end{array}$ & $8,0^{1}$ & $5,3^{1}$ & $4,0^{1}$ & $1,8^{1}$ & $2,9^{1}$ & $3,2^{1}$ & $3,0^{1}$ & $4,4^{1}$ & $8,2^{1}$ & $2,4^{2}$ \\
\hline \begin{tabular}{l}
\multicolumn{1}{c}{ Америк } \\
анский \\
регион
\end{tabular} & $2,4^{2}$ & $2,9^{2}$ & $8,0^{2}$ & $1,8^{3}$ & $6,9^{3}$ & $0,1^{4}$ & $3,9^{4}$ & $3,9^{4}$ & $8,1^{3}$ & $2,3^{3}$ \\
\hline $\begin{array}{c}\text { Восточ } \\
\text { но- } \\
\text { Средиземно } \\
\text { морский } \\
\text { регион } \\
\end{array}$ & $2^{5}$ &, $8^{4}$ & 6 & $6^{5}$ & ,5 & , & 8 & 3 & 9 & $0^{1}$ \\
\hline $\begin{array}{c}\text { Юго- } \\
\text { Восточная } \\
\text { Азия }\end{array}$ & $1,6^{5}$ & $3,7^{5}$ & $9,6^{4}$ & $6,1^{4}$ & $7,6^{3}$ & $2,1^{3}$ & $5,7^{2}$ & $2,7^{2}$ & $2,7^{2}$ & $3,1^{2}$ \\
\hline $\begin{array}{r}\text { Африка } \\
\text { нский регион }\end{array}$ &, $5^{0}$ &, $7^{0}$ &, $9^{0}$ &, $3^{1}$ &, $7^{1}$ & $0^{3}$ &, $8^{4}$ & ${ }^{4}{ }^{6}$ &, $2^{7}$ & $4^{7}$ \\
\hline
\end{tabular}




\section{Американский регион}

В регионе на анализируемой неделе отмечено снижение числа новых случаев заболевания на 6\% в сравнении с предыдущей неделей (рисунок 4).

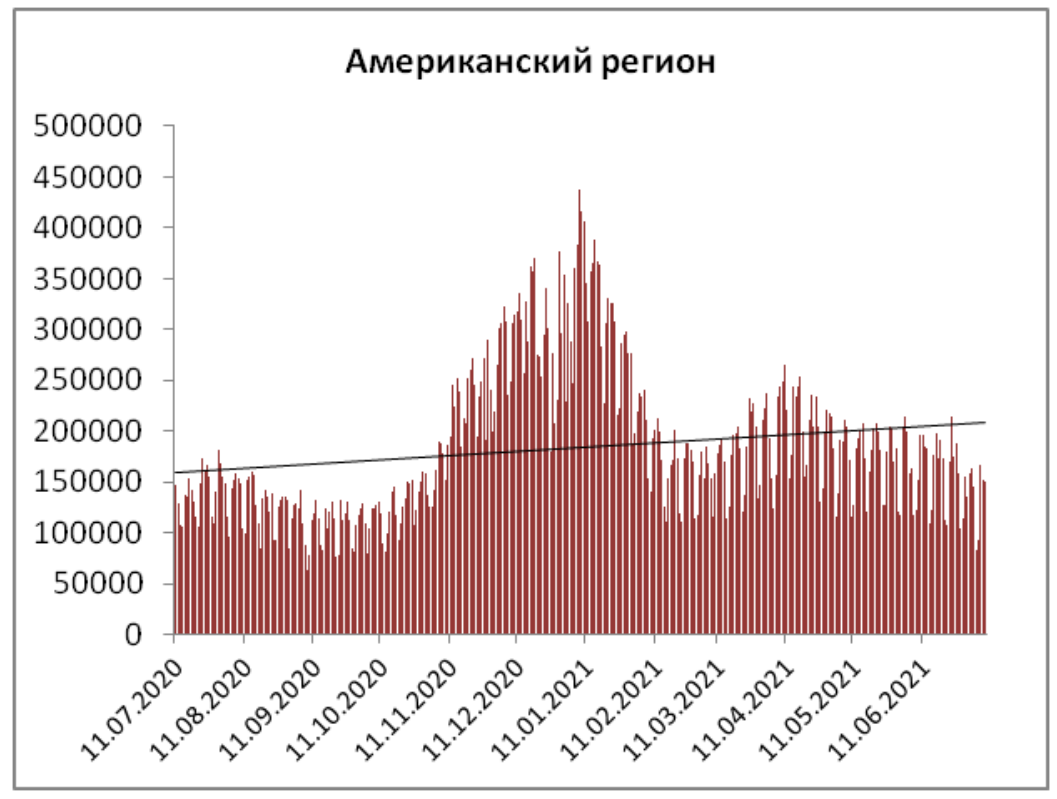

Рисунок 4 - Динамика ежедневного прироста новых случаев в Американском регионе

Количество стран региона, в которых зафиксирован рост числа новых случаев за неделю составило 18, наибольший по сравнению с предыдущей неделей - в Сальвадоре и Гватемале (таблица 4).

Таблица 4 - Страны с максимальным увеличением количества случаев, зарегистрированных за неделю (при сравнении недели с 26 июня по 2 июля и недели 3 по 9 июля)

\begin{tabular}{|c|c|c|c|c|c|}
\hline \multirow{3}{*}{ Страна } & \multicolumn{4}{|c|}{ Зарегистрировано } & \multirow{3}{*}{ 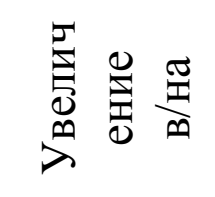 } \\
\hline & \multicolumn{2}{|c|}{ с 26 июня по 2 июля } & \multicolumn{2}{|c|}{ с 3 по 9 июля } & \\
\hline & абс. число & на 1 млн & абс. число & на 1 млн & \\
\hline Сальвадор & 1282 & 198,6 & 2166 & 335,6 & $69 \%$ \\
\hline Гватемала & 9730 & 550,3 & 14904 & 843,0 & В 1,5 раза \\
\hline
\end{tabular}

На анализируемой неделе среди стран региона по числу еженедельно выявляемых случаев доминируют Бразилия, Аргентина и Колумбия. Удельный 
вес новых случаев в общей заболеваемости в Американском регионе в этих трех странах на неделе составил 67,3\% (рисунок 5).

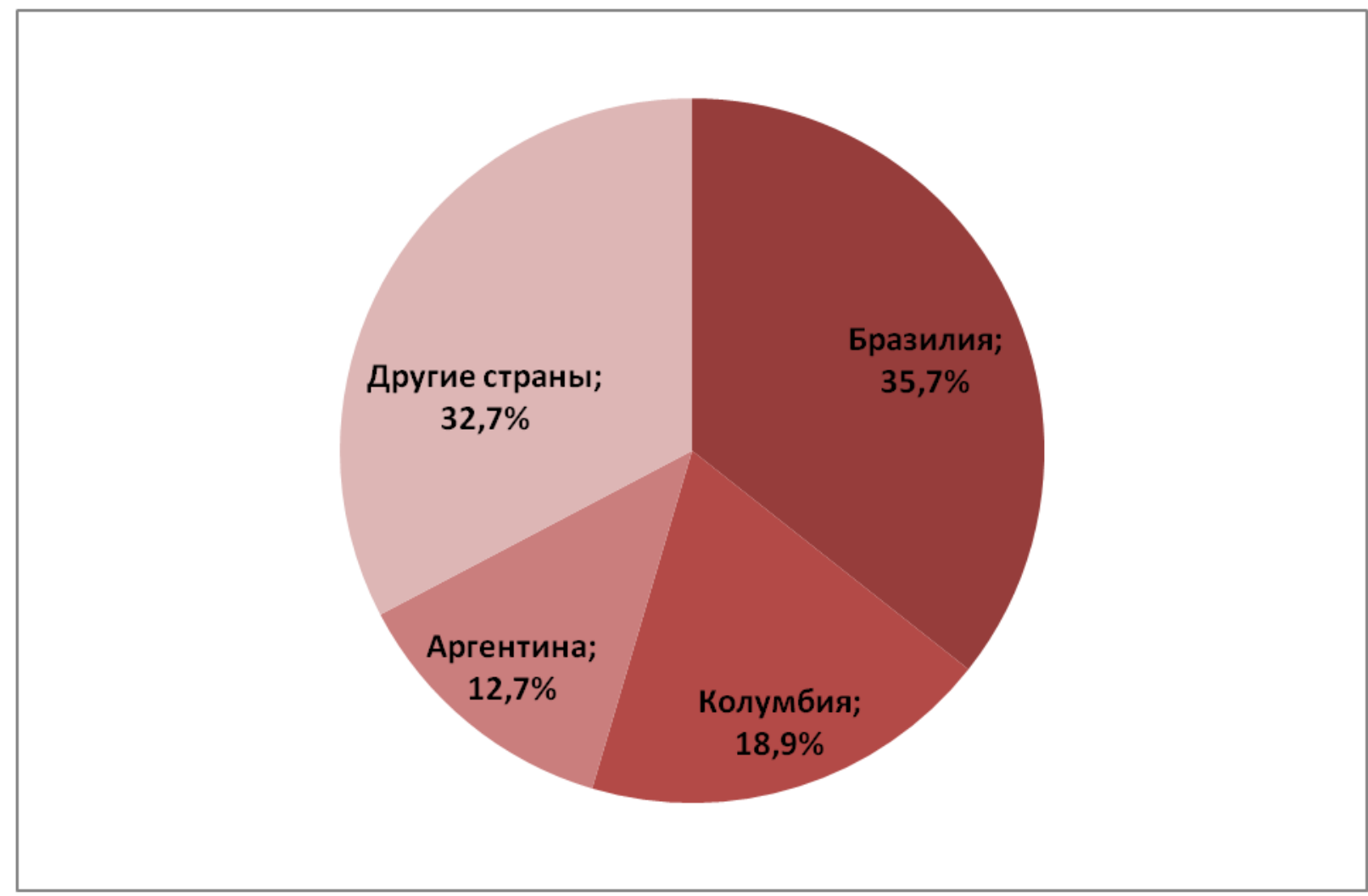

Рисунок 5 - Доля Бразилии, Аргентины, Колумбии и других стран в количестве случаев, зарегистрированных за отчетную неделю

Наибольшее число заболевших в регионе на 1 млн населения за последнюю неделю, зарегистрировано в Колумбии (3746), Аргентине (2703), Кубе (2157). Наибольшее число летальных исходов на 1 млн населения за последнюю неделю зарегистрировано в Парагвае (100), Колумбии (83), Аргентине (70).

В настоящее время отмечается интенсивный рост уровня заболеваемости в Мексике (рисунок 6). За последнюю неделю зарегистрировано на 32\% больше случаев, чем неделей ранее. При этом в СМИ отмечается, что вопреки новой волне коронавируса, количество госпитализаций и смертей удается держать под контролем благодаря вакцинации населения. Койки в больницах заполнены лишь на $20 \%$. 


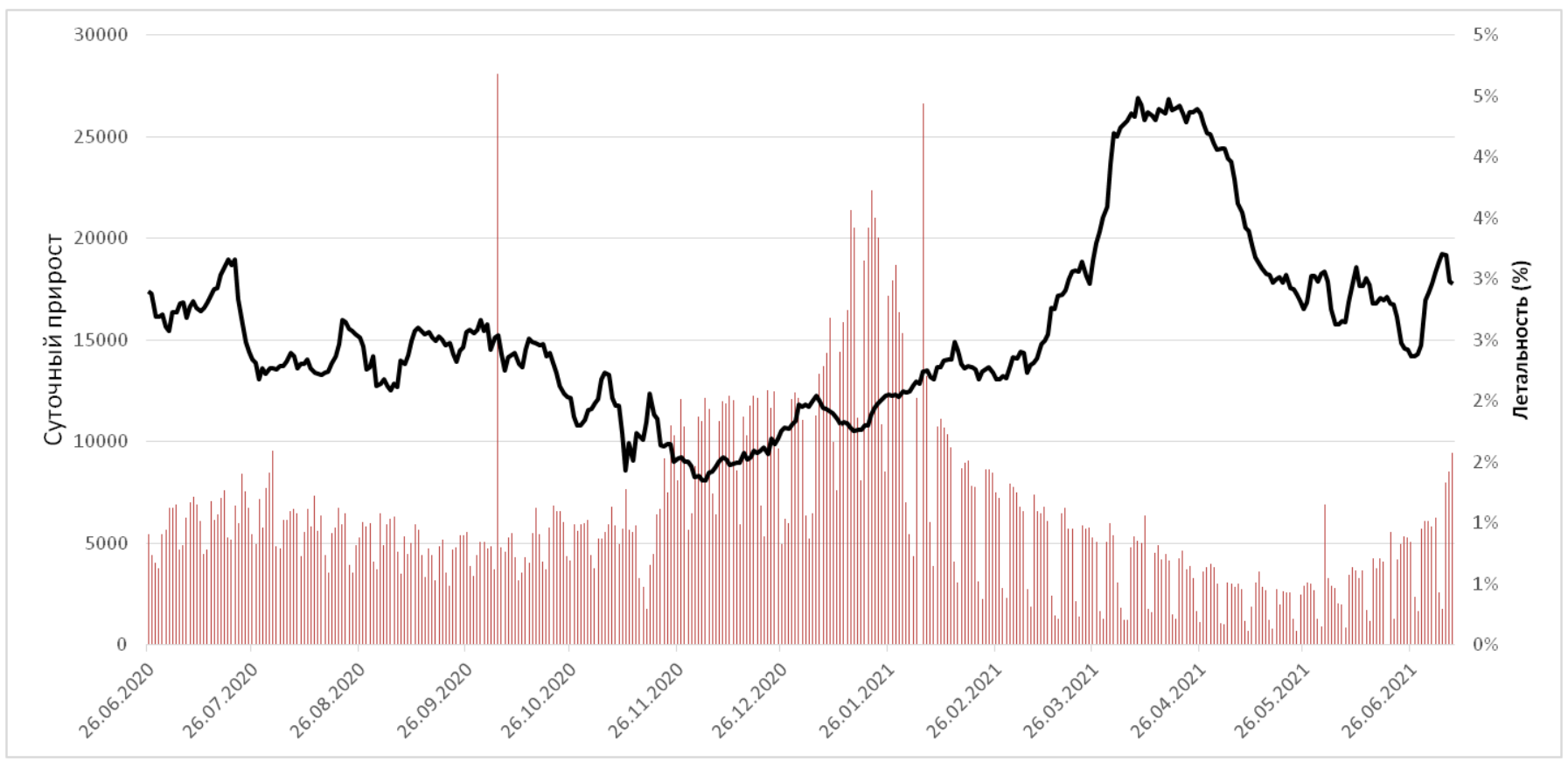

Рисунок 6 - Динамика ежесуточного прироста новых случаев заболевания и летальности в Мексике (как отношения средних показателей прироста смертей и случаев за 7-дневный период)

В регионе Северной и Южной Америки наибольшее число случаев за неделю регистрируется в Бразилии (рисунок 7).

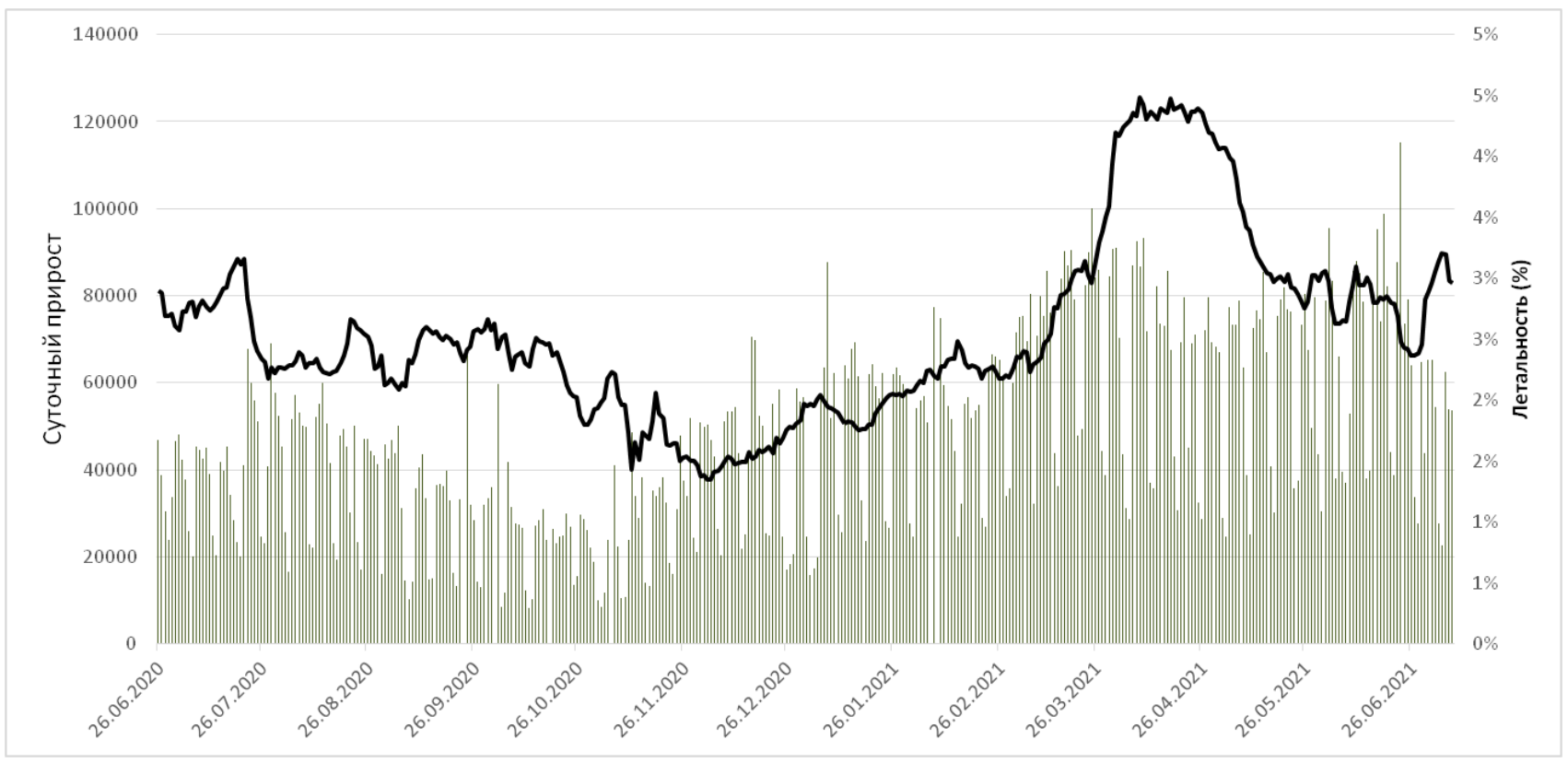


Рисунок 7 - Динамика ежесуточного прироста новых случаев в Бразилии (как отношения средних показателей прироста смертей и случаев за 7-дневный период) 


\section{Страны Европейского региона}

В Европейском регионе на анализируемой неделе отмечен рост числа новых случаев заражения на $35,8 \%$ в сравнении с предыдущей неделей (рисунок $8)$.

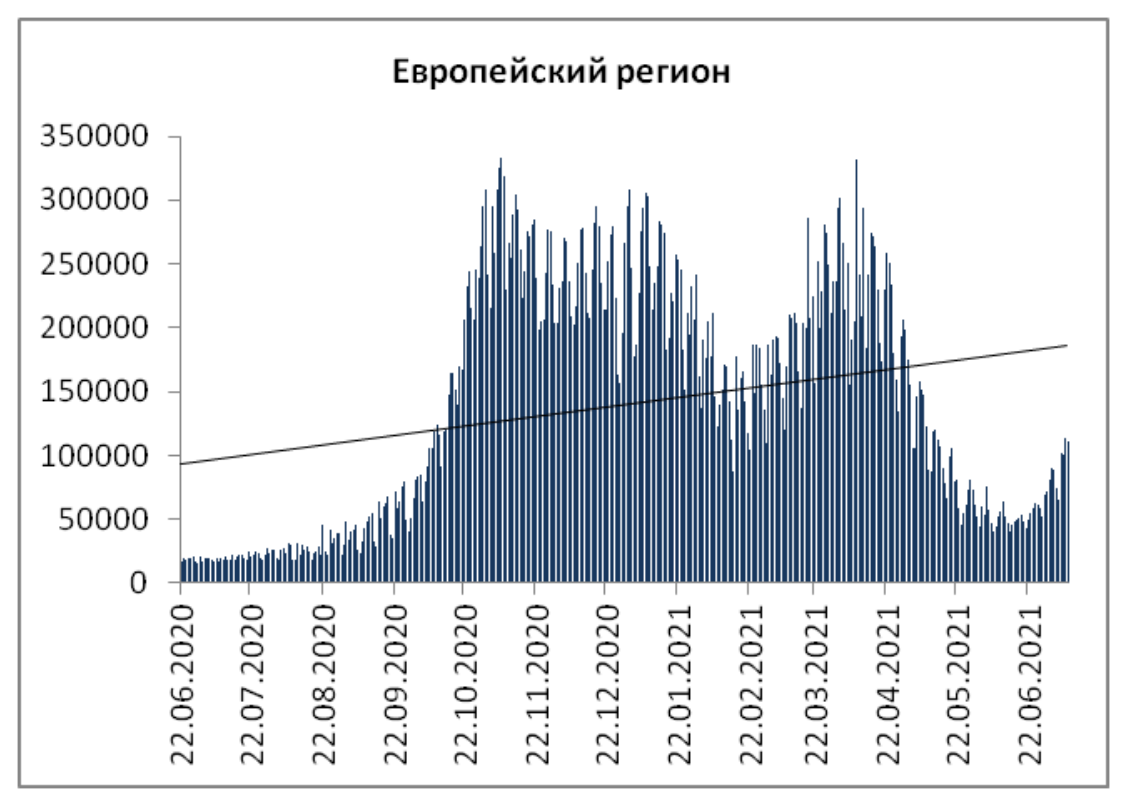

Рисунок 8 - Динамика ежедневного прироста новых случаев в Европейском регионе

Рост заболеваемости за неделю отмечен в 41 из 56 стран региона, наибольший - в Нидерландах, Греции и на Кипре (таблица 5). 
Таблица 5 - Страны с максимальным увеличением количества случаев, зарегистрированных за неделю (при сравнении недели с 26 июня по 2 июля и недели 3 по 9 июля)

\begin{tabular}{|c|c|c|c|c|c|}
\hline \multirow{3}{*}{ Страна } & \multicolumn{4}{|c|}{ Зарегистрировано } & \multirow{3}{*}{ 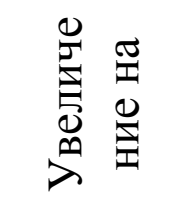 } \\
\hline & \multicolumn{2}{|c|}{ с 26 июня по 2 июля } & \multicolumn{2}{|c|}{ с 3 по 9 июля } & \\
\hline & абс. число & на 1 млн & абс. число & на 1 млн & \\
\hline Нидерланды & 4321 & 246,7 & 16133 & 921 & $\begin{array}{c}\text { в } \sim 3,7 \\
\text { раза }\end{array}$ \\
\hline Греция & 3276 & 305,0 & 9836 & 915,7 & в 3 раза \\
\hline Кипр & 2159 & 2464,9 & 5248 & 5991,6 & $\begin{array}{c}\text { в } \sim 2,5 \\
\text { раза }\end{array}$ \\
\hline
\end{tabular}

Наибольшее число инфицированных на 1 млн населения в регионе за неделю с 3 по 9 июля зафиксировано на Кипре (5992), в Великобритании (2929), Испании (2003).

Наибольшее число летальных исходов на 1 млн населения за последнюю неделю отмечено в Абхазии $(32,8)$, Грузии $(23,6)$ и Румынии $(15,8)$.

Самый высокий показатель по числу инфицированных в регионе за последнюю неделю зарегистрирован в Великобритании (рисунок 9). За неделю с 3 по 9 июля в стране зарегистрирован 195181 случай заболевания. 


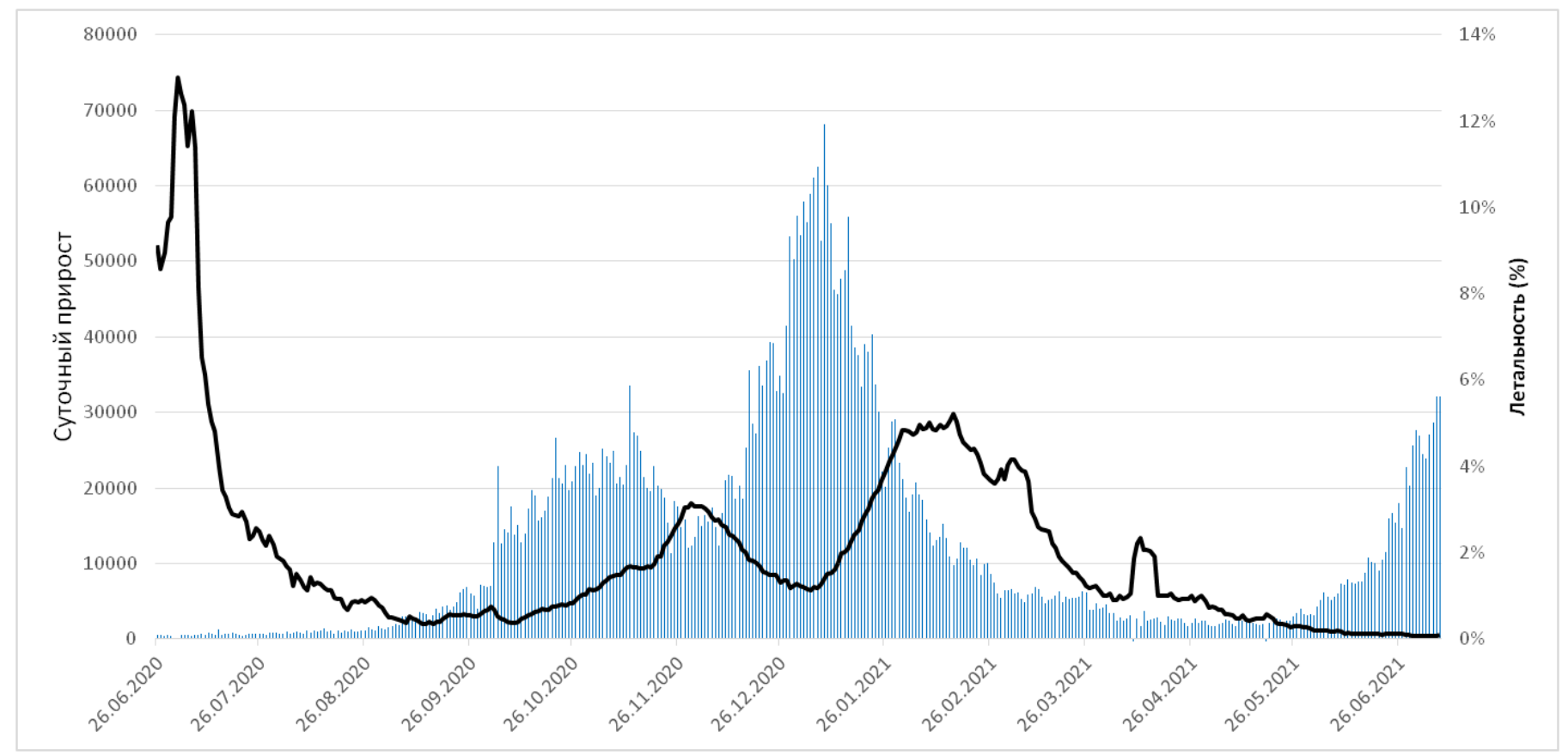

Рисунок 9 - Динамика ежесуточного прироста новых случаев заболе-вания и летальности в Великобритании (как отношения средних показателей прироста смертей и случаев за 7-дневный период)

Рост заболеваемости COVID-19 в настоящее время регистрируется в Нидерландах (рисунок 10). Рост может быть связан с отменой 26 июня большинства ограничений: открылись рестораны, бары, ночные клубы. Около трёх четвертей новых случаев приходится на молодых людей (большинству из них пока недоступна вакцина). В СМИ появляются сообшения о вспышках, связанных с ночными клубами. 


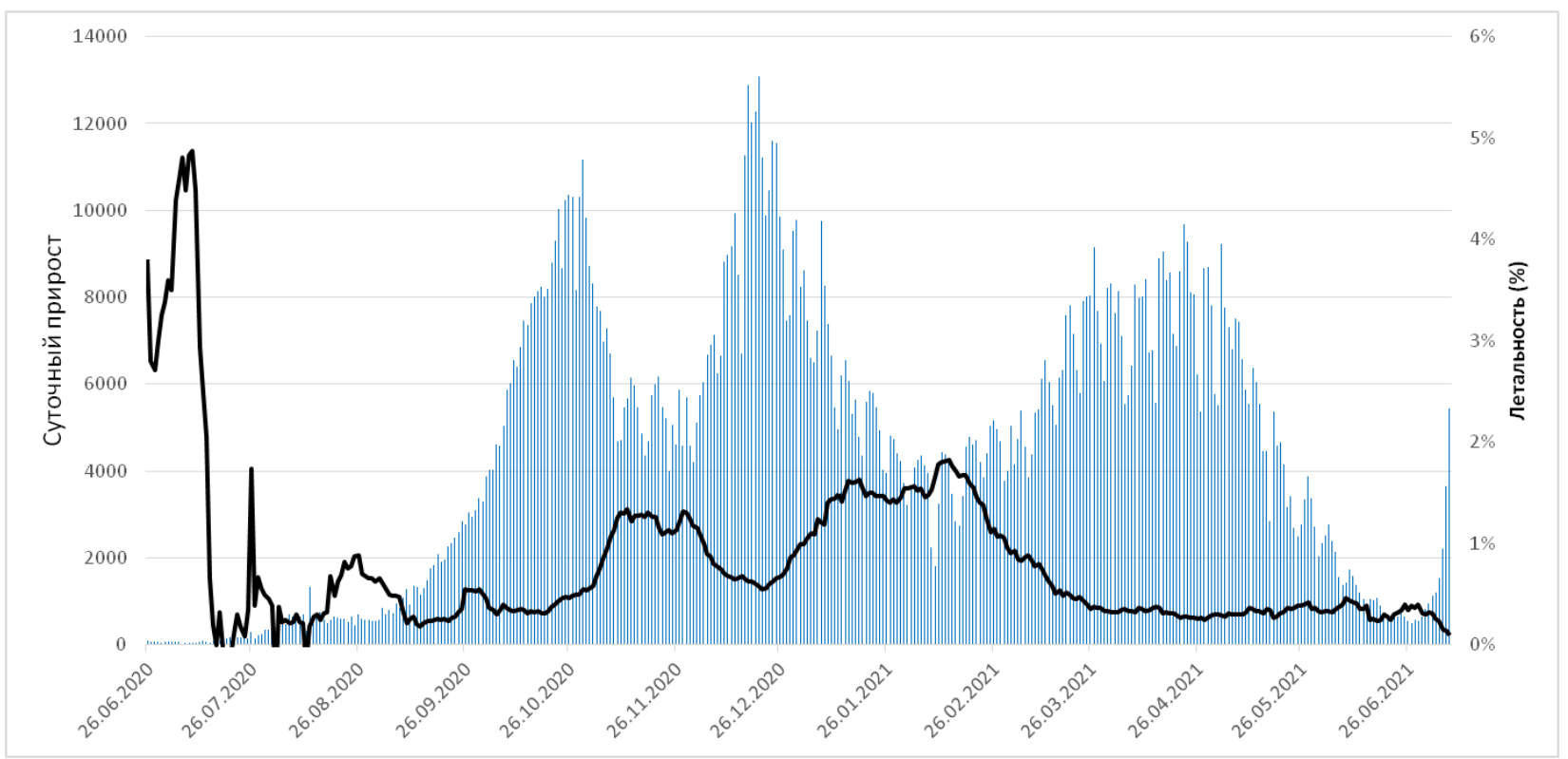

Рисунок 10 - Динамика ежесуточного прироста новых случаев заболевания и летальности в Нидерландах (как отношения средних показателей прироста смертей и случаев за 7-дневный период)

Доля выявленных случаев в странах СНГ от всех зарегистрированных в Европейском регионе составила 32,5\% - некоторое снижение по сравнению с прошлой неделей (рисунок 11).

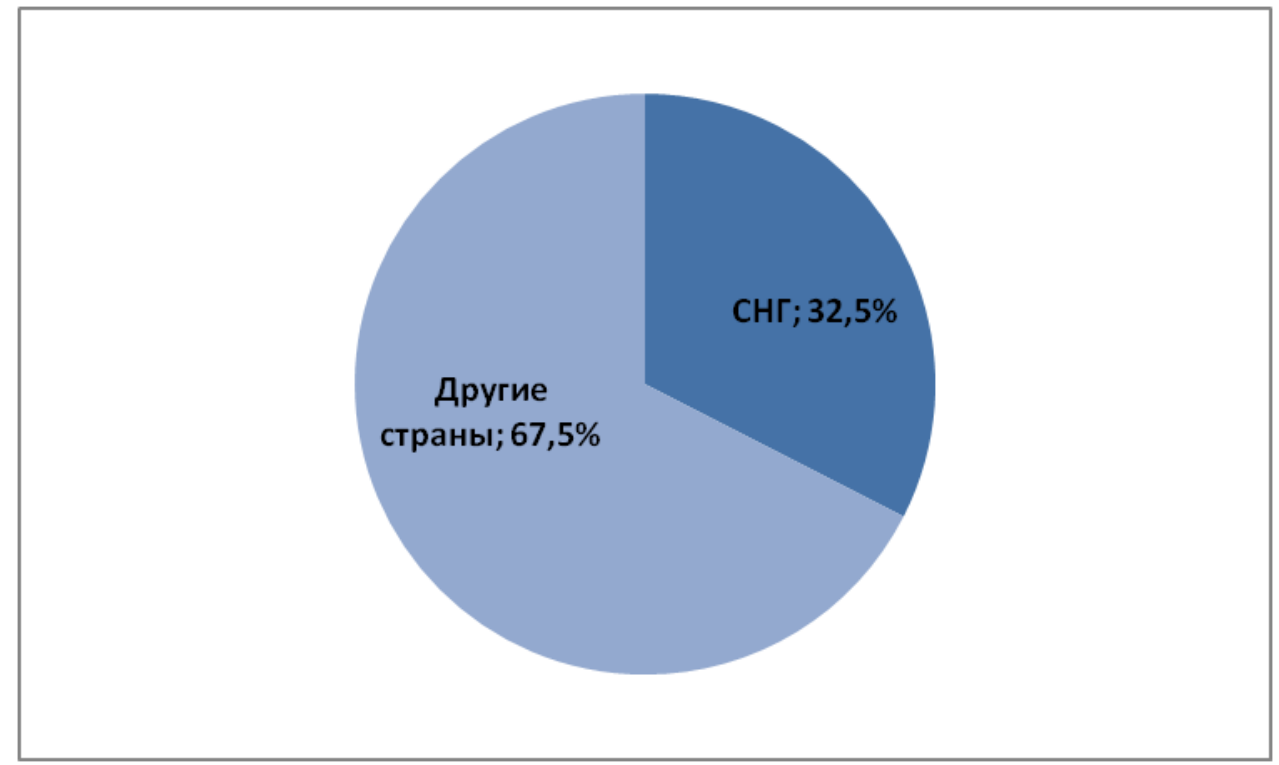

Рисунок 11 - Доля стран СНГ и других стран в количестве случаев, зарегистрированных за отчетную неделю в Европейском регионе 
На анализируемой неделе в Западно-Тихоокеанском регионе отмечен рост заболеваемости на 12,7\% в сравнении с прошлой неделей (рисунок 12).

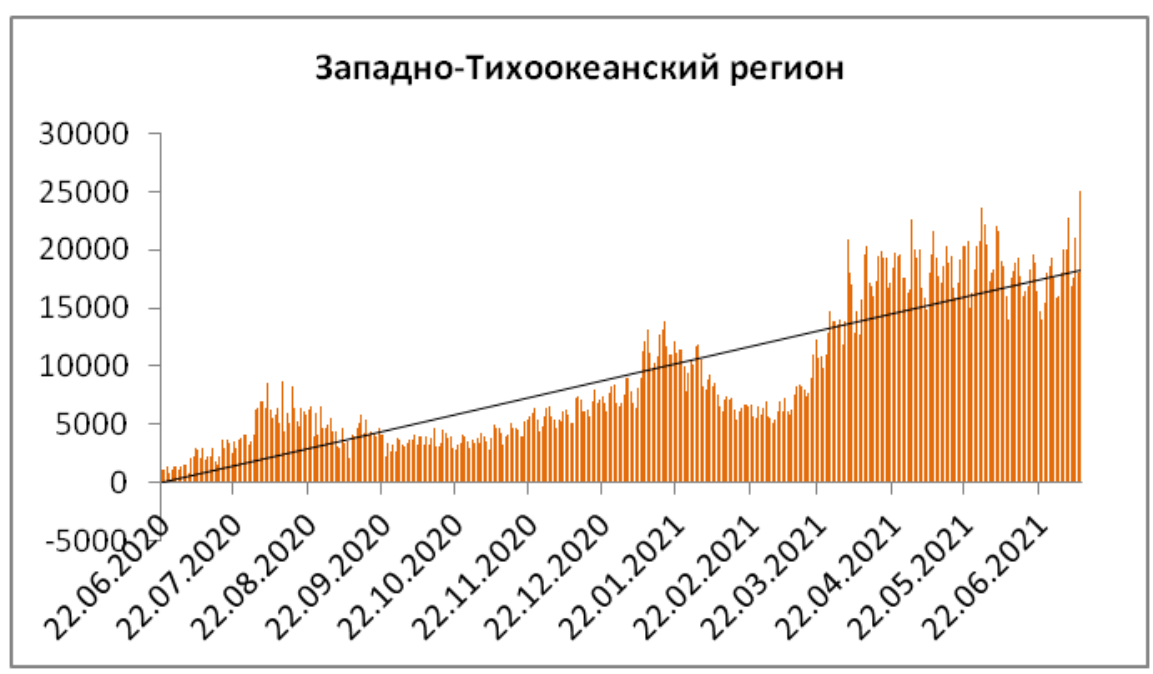

Рисунок 12 - Динамика ежедневного прироста новых случаев в Западно-Тихоокеанском регионе

В 11 странах региона зафиксирован рост числа новых случаев за неделю, наибольший - во Вьетнаме (таблица 6).

Таблица 6 - Страны с максимальным увеличением количества случаев, зарегистрированных за неделю (при сравнении недели с 26 июня по 2 июля и недели 3 по 9 июля)

\begin{tabular}{|c|c|c|c|c|c|}
\hline \multirow{3}{*}{ Страна } & \multicolumn{4}{|c|}{ Зарегистрировано } & \multirow{3}{*}{ 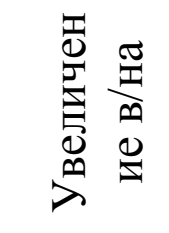 } \\
\hline & \multicolumn{2}{|c|}{ с 26 июня по 2 июля } & \multicolumn{2}{|c|}{ с 3 по 9 июля } & \\
\hline & абс. число & на 1 млн & абс. число & на 1 млн & \\
\hline Вьетнам & 3404 & 35,4 & 7083 & 73,6 & $\begin{array}{l}\text { в } ~ 2 \\
\text { раза }\end{array}$ \\
\hline Фиджи & 2001 & 2248,3 & 3812 & 4283,1 & На $90 \%$ \\
\hline
\end{tabular}

На Малайзию и Филиппины приходится 61,5\% от всех выявленных случаев за неделю с 3 по 9 июля в Западно-Тихоокеанском регионе (рисунок 13). 


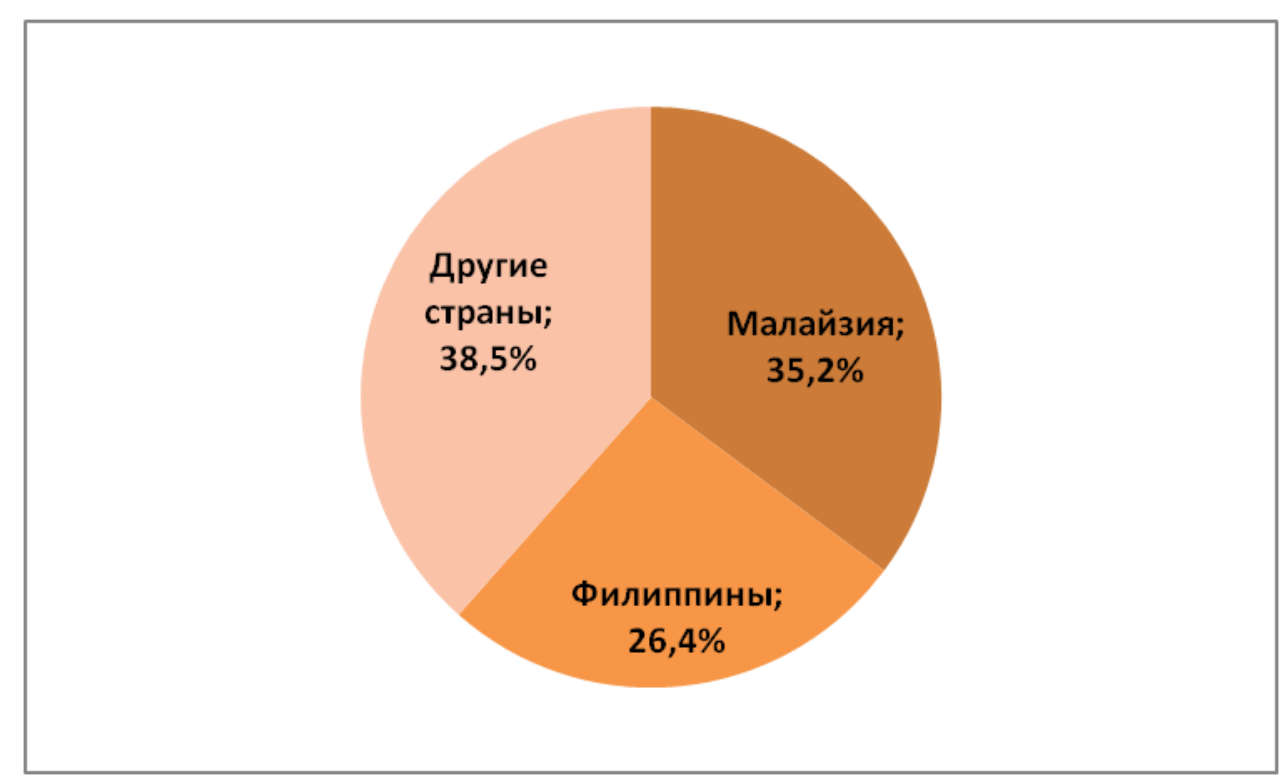

Рисунок 13 - Доля Филиппин, Малайзии и других стран в количестве случаев, зарегистрированных за отчетную неделю

В регионе наибольшее число новых случаев заражения на 1 млн населения за неделю зарегистрировано в Монголии (4853) и на Фиджи (4283). Наибольшее число летальных исходов на 1 млн населения зафиксировано на Фиджи (27), в Монголии (24) и Малайзии $(19,6)$.

Во Вьетнаме с начала мая наблюдается поступательный рост заболеваемости COVID-19 (рисунок 14), число новых случаев резко возросло за последнюю неделю. В Хошимине - самом крупном во Вьетнаме городе, с населением более 9 млн человек, - с 09.07.21 г. начинает действовать двухнедельный режим изоляции. Людям, оказавшимся в тесном контакте с инфицированными, разрешено изолироваться дома, поскольку государственные центры для изоляции переполнены. 


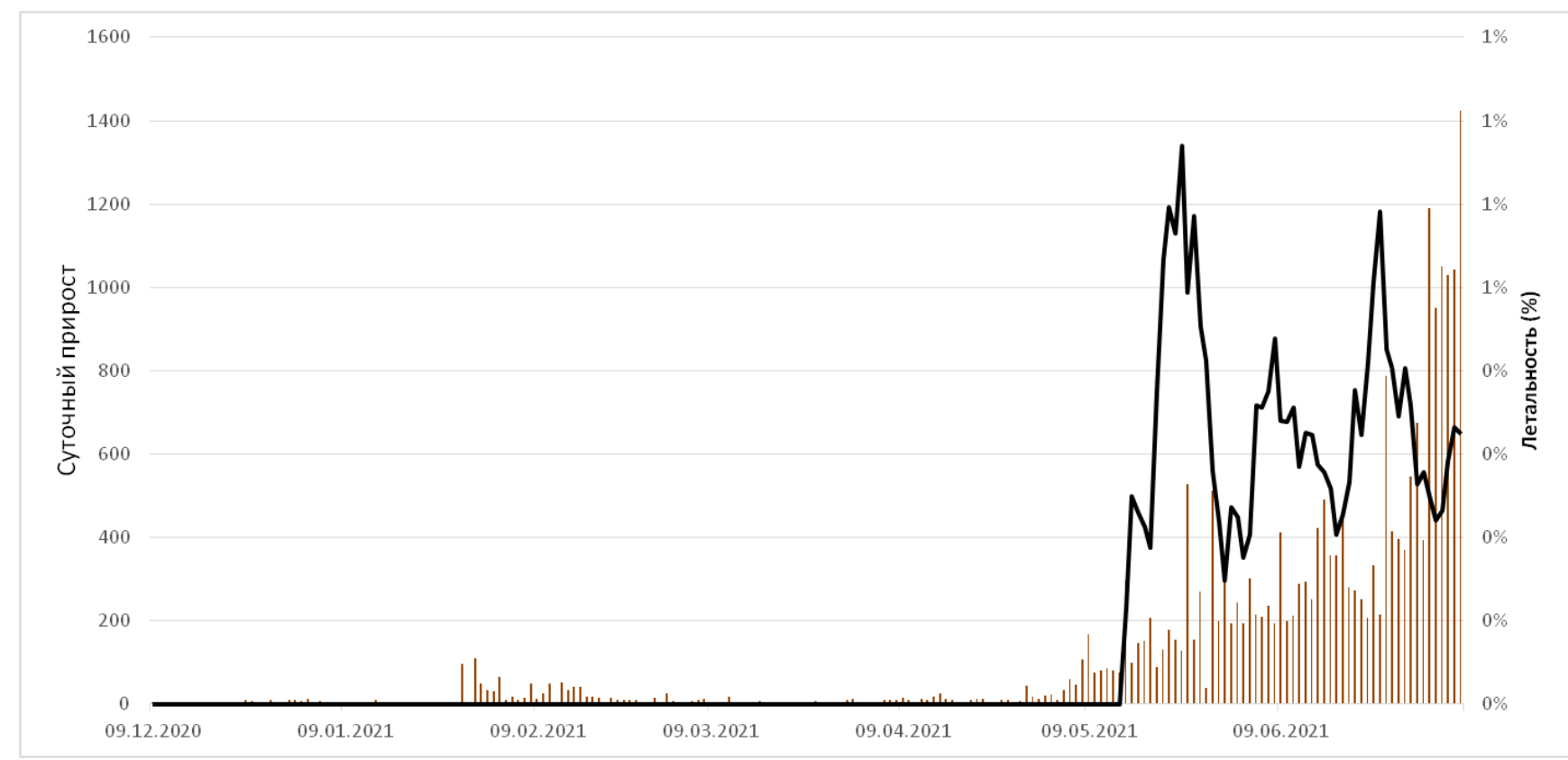

Рисунок 14 - Динамика ежесуточного прироста новых случаев и летальности во Вьетнаме (как отношения средних показателей прироста смертей и случаев за 7-дневный период) 


\section{Восточно-Средиземноморский регион}

В регионе на анализируемой неделе наблюдается увеличение числа новых случаев заболевания на 22,6\% в сравнении с прошлой неделей (рисунок 15).

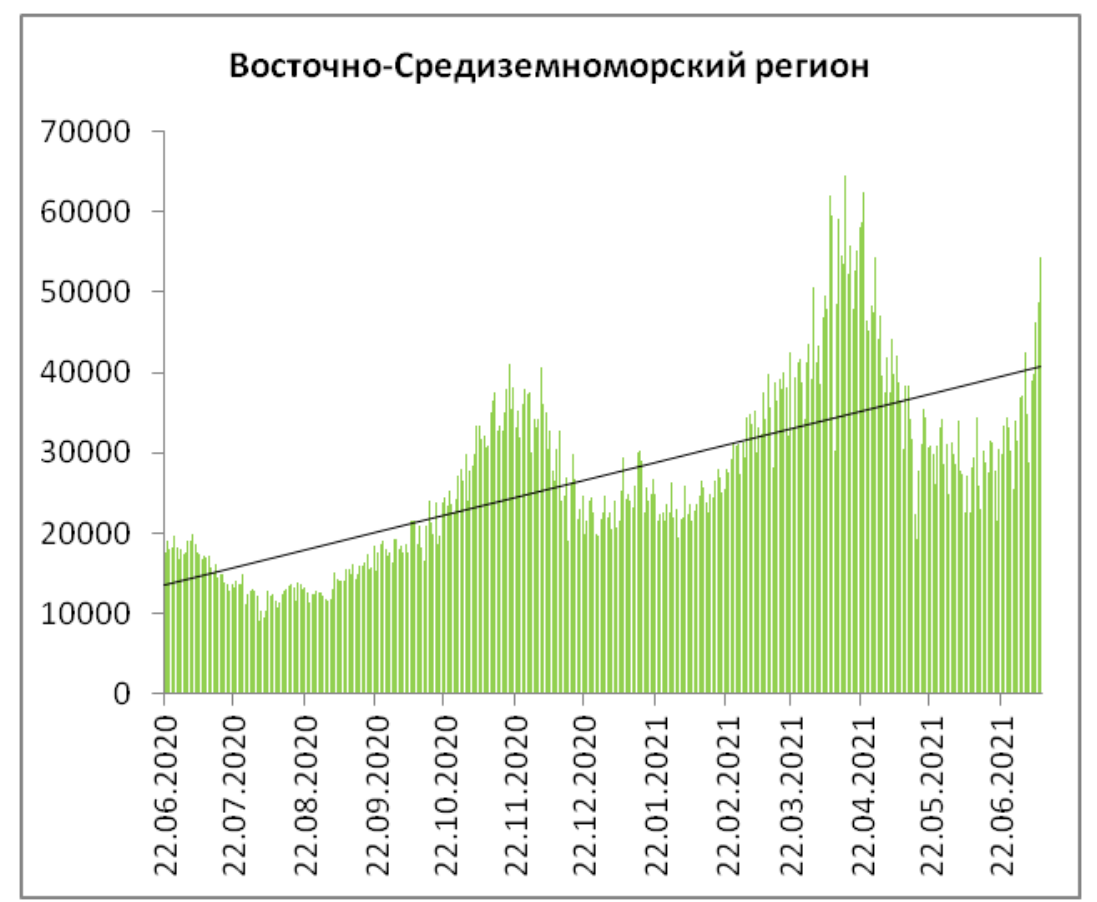

Рисунок 15 - Динамика ежедневного прироста новых случаев в Восточно-

Средиземноморском регионе

За неделю с 3 по 9 июля в 10 из 22 стран региона отмечен рост числа новых случаев. Максимальное увеличение недельного прироста зафиксировано в Ливии и Ливане (таблица 7). 
Таблица 7 - Страны с максимальным увеличением количества случаев, зарегистрированных за неделю (при сравнении недели с 26 июня по 2 июля и недели 3 по 9 июля)

\begin{tabular}{|c|c|c|c|c|c|}
\hline \multirow{2}{*}{ Страна } & \multicolumn{4}{|c|}{ Зарегистрировано } & \multirow{2}{*}{} \\
\cline { 2 - 5 } & с 26 июня по 2 июля & \multicolumn{2}{|c|}{ с 3 по 9 июля } & \\
\cline { 2 - 5 } & абс. число & на 1 млн & абс. число & на 1 млн & В 2,5 \\
Ливия & 2245 & 331,3 & 5621 & 829,4 & раза \\
\hline Ливан & 1014 & 147,9 & 1750 & 255,3 & На 73\% \\
\hline
\end{tabular}

На Иран приходится 37,3\% от всех выявленных случаев за неделю с 3 по 9 июля в Восточно-Средиземноморском регионе (рисунок 16).

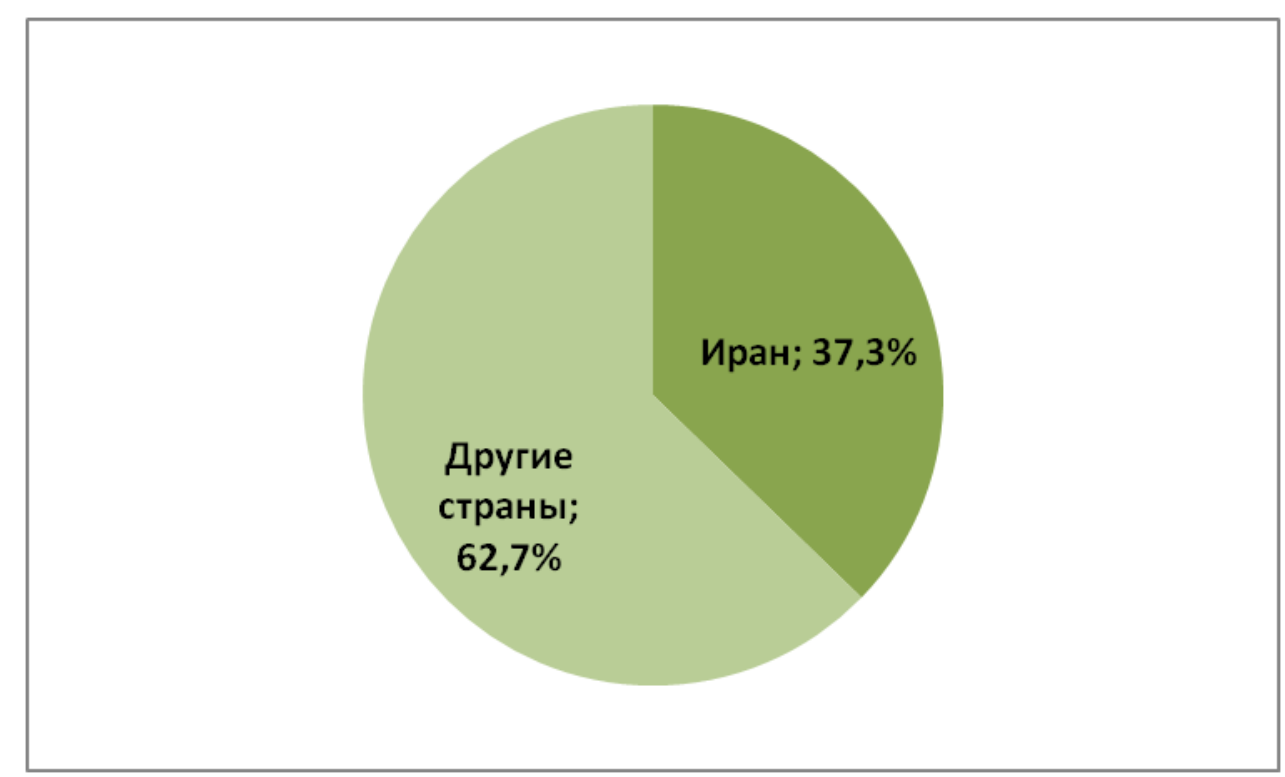

Рисунок 16 - Удельный вес Ирана и других стран в структуре случаев в ВосточноСредиземноморском регионе

Наибольшее число заболевших на 1 млн населения за последнюю неделю зарегистрировано в Тунисе (3954), Кувейте (2953), Омане (2735). Наибольшее 
число летальных исходов на 1 млн населения за последнюю неделю зарегистрировано в Тунисе (68), Омане (56).

В Тунисе - резкий рост заболеваемости: за последнюю неделю зарегистрировано на 47\% случаев больше, чем неделей ранее. Система здравоохранения Туниса не справляется с нагрузками, возникшими из-за резкого роста заболеваемости COVID-19 в стране, заявила 7 июля официальный представитель тунисского минздрава. По словам представителя министерства, сейчас власти предпринимают все возможные усилия, чтобы обеспечить больницы кислородом.

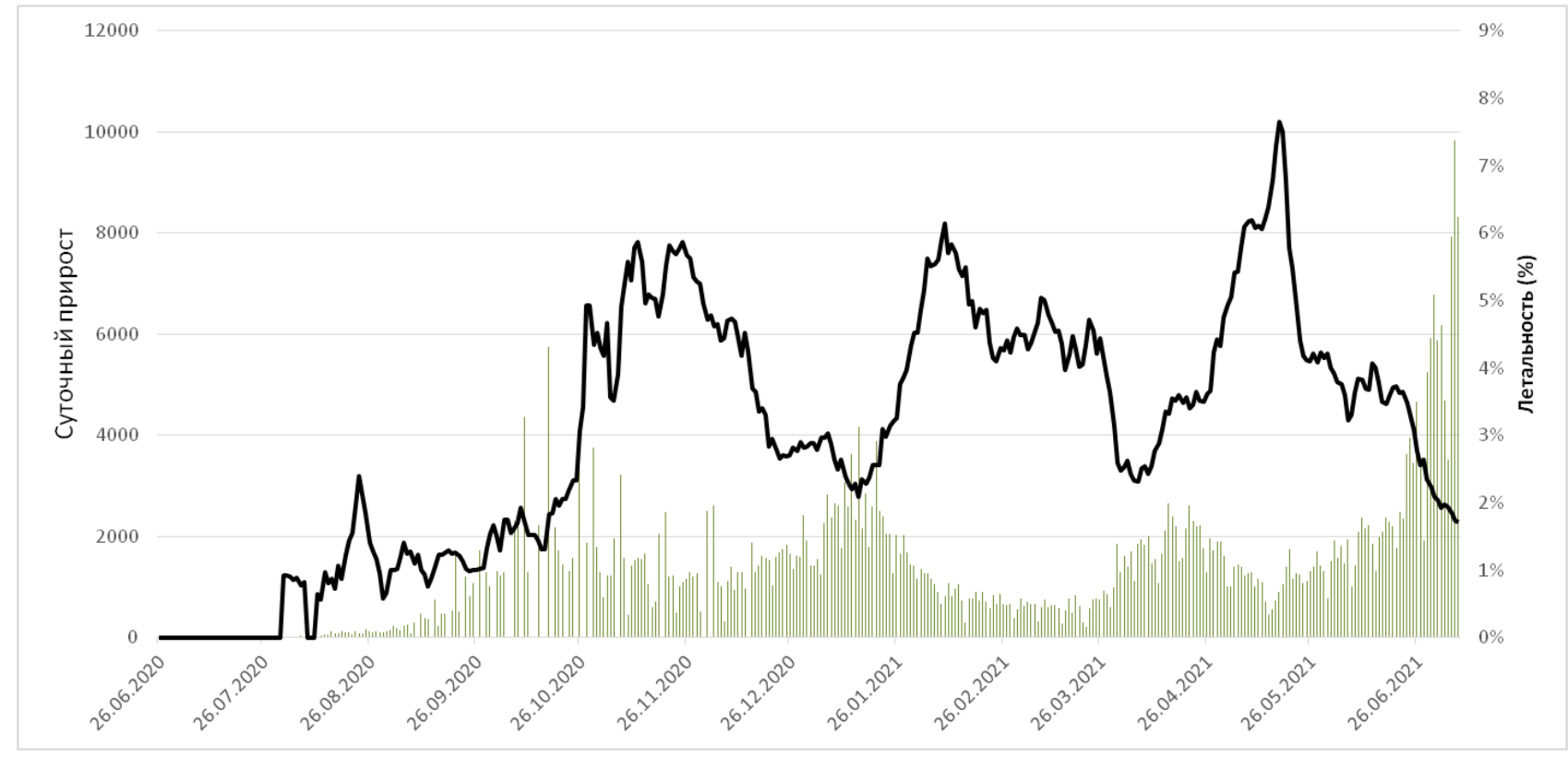

Рисунок 17 - Динамика ежесуточного прироста новых случаев заболевания и летальности в Тунисе (как отношения средних показателей прироста смертей и случаев за 7-дневный период). 


\section{Юго-Восточная Азия}

В регионе на анализируемой неделе наблюдается рост числа новых случаев на $12,2 \%$ в сравнении с прошлой неделей (рисунок 18 ).

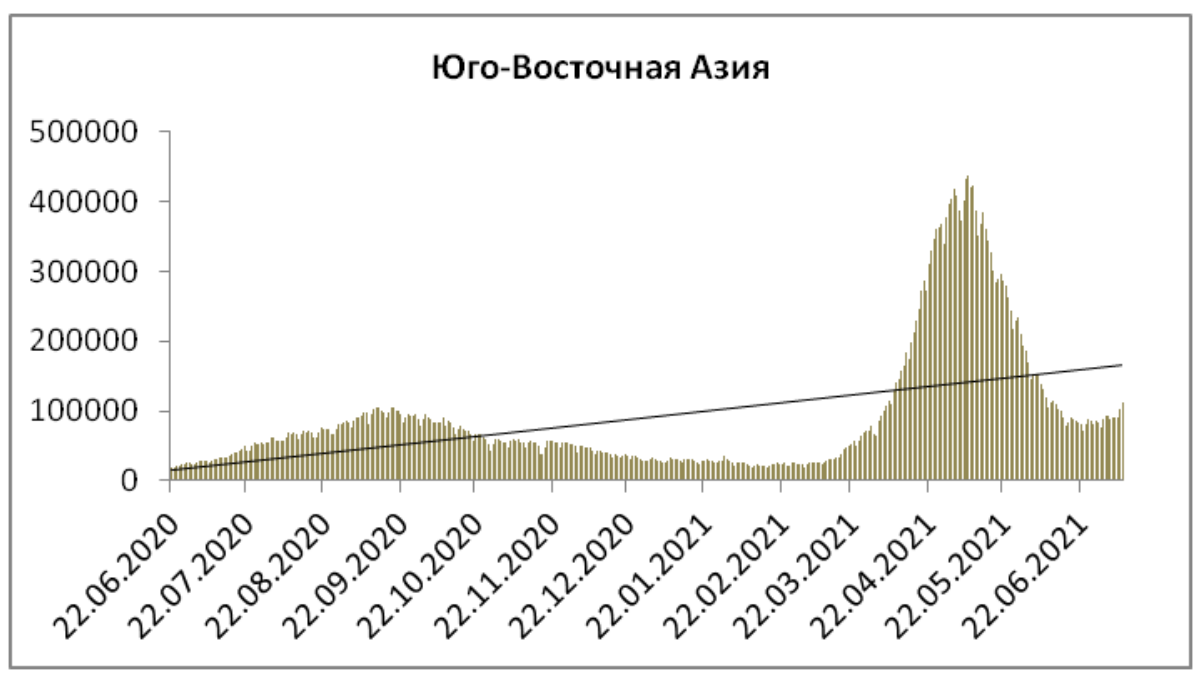

Рисунок 18 - Динамика ежедневного прироста новых случаев в Юго-Восточной Азии

Увеличение прироста случаев за неделю отмечено в 5 из 10 стран региона наибольшее в Мьянме, Индонезии и Бангладеш (таблица 8). 
Таблица 8 - Страны с максимальным увеличением количества случаев, зарегистрированных за неделю (при сравнении недели с 26 июня по 2 июля и недели 3 по 9 июля).

\begin{tabular}{|c|c|c|c|c|c|}
\hline \multirow{3}{*}{ Страна } & \multicolumn{4}{|c|}{ Зарегистрировано } & \multirow{3}{*}{ 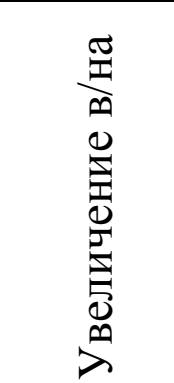 } \\
\hline & \multicolumn{2}{|c|}{ с 26 июня по 2 июля } & \multicolumn{2}{|c|}{ с 3 по 9 июля } & \\
\hline & абс. число & на 1 млн & абс. число & на 1 млн & \\
\hline Мьянма & 8633 & 159,7 & 20708 & 383,2 & $\begin{array}{c}\text { В 2,4 } \\
\text { раза }\end{array}$ \\
\hline Индонезия & 149113 & 558,7 & 214680 & 804,3 & $\mathrm{Ha} 44 \%$ \\
\hline Бангладеш & 48624 & 282,9 & 67660 & 393,6 & На $40 \%$ \\
\hline
\end{tabular}

На Индию приходится 44,6\% от всех выявленных за неделю случаев в ЮгоВосточной Азии в период с 3 по 9 июля (рисунок 19).

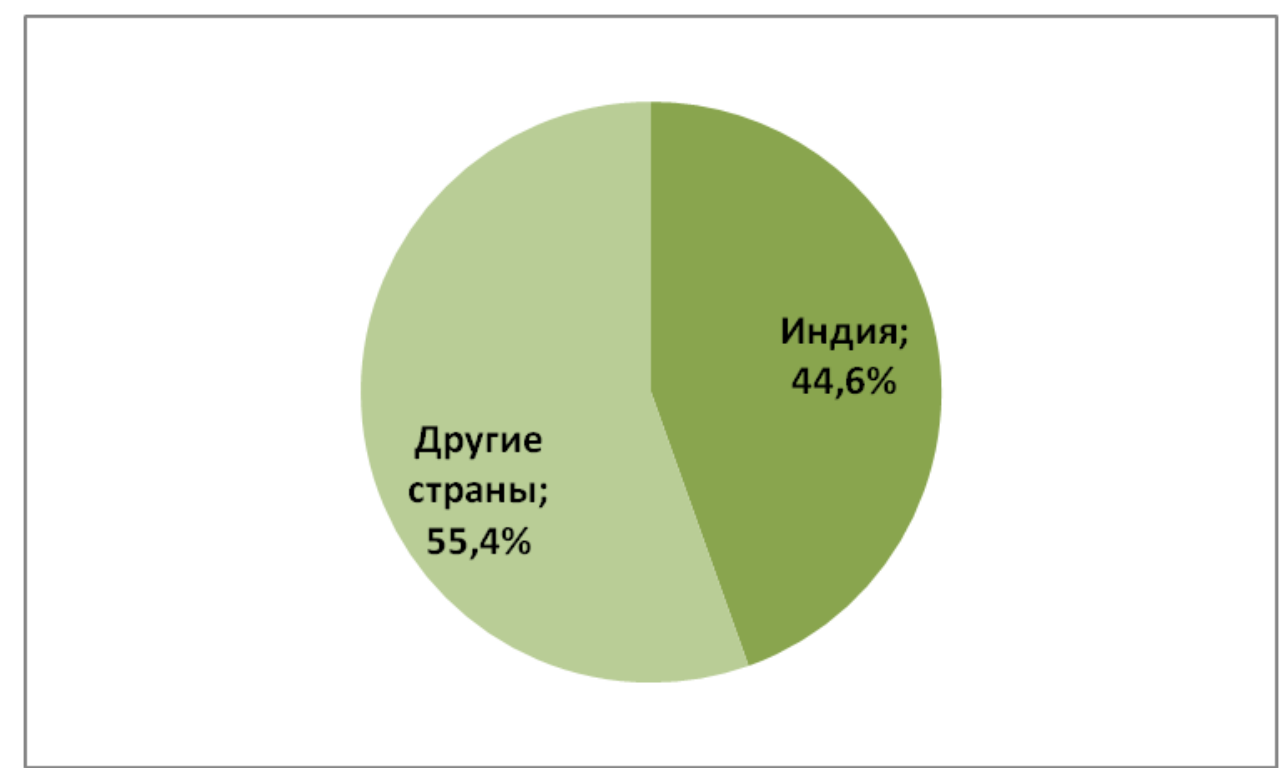

Рисунок 19 - Доля Индии и других стран региона в количестве случаев, зарегистрированных за отчетную неделю

Наибольшее число заболевших на 1 млн населения за последнюю неделю зарегистрировано на Мальдивах (1668) и в Индонезии (804). Наибольшее число 
летальных исходов на 1 млн населения за последнюю неделю в регионе зарегистрировано в Индонезии (18) и Шри-Ланке (12,4) (Рис. 20).

Особенно резкий рост уровня заболеваемости наблюдается в Мьянме. Число инфицированных за последнюю неделю в 2,4 раза превышает показатель недели ранее. Власти Мьянмы решили с 9 июля вновь закрыть школы в стране из-за роста заболеваемости.

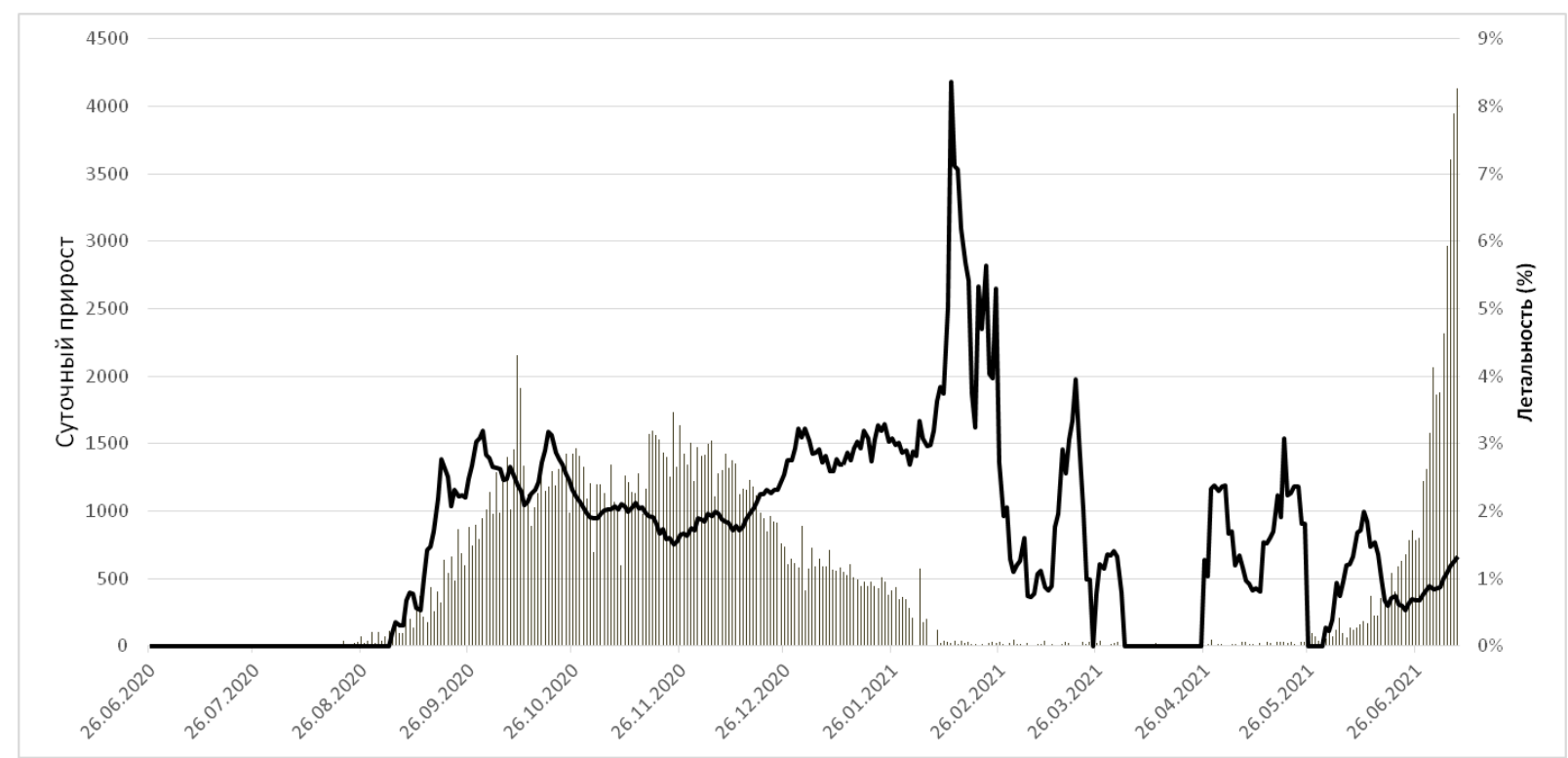

Рисунок 20 - Динамика ежесуточного прироста новых случаев заболевания и летальности в Мьянме (как отношения средних показателей прироста смертей и случаев за 7-дневный период) 


\section{Африканский регион}

В регионе на анализируемой неделе наблюдается увеличение числа новых случаев заболевания на 12\% в сравнении с прошлой неделей (рисунок 21).

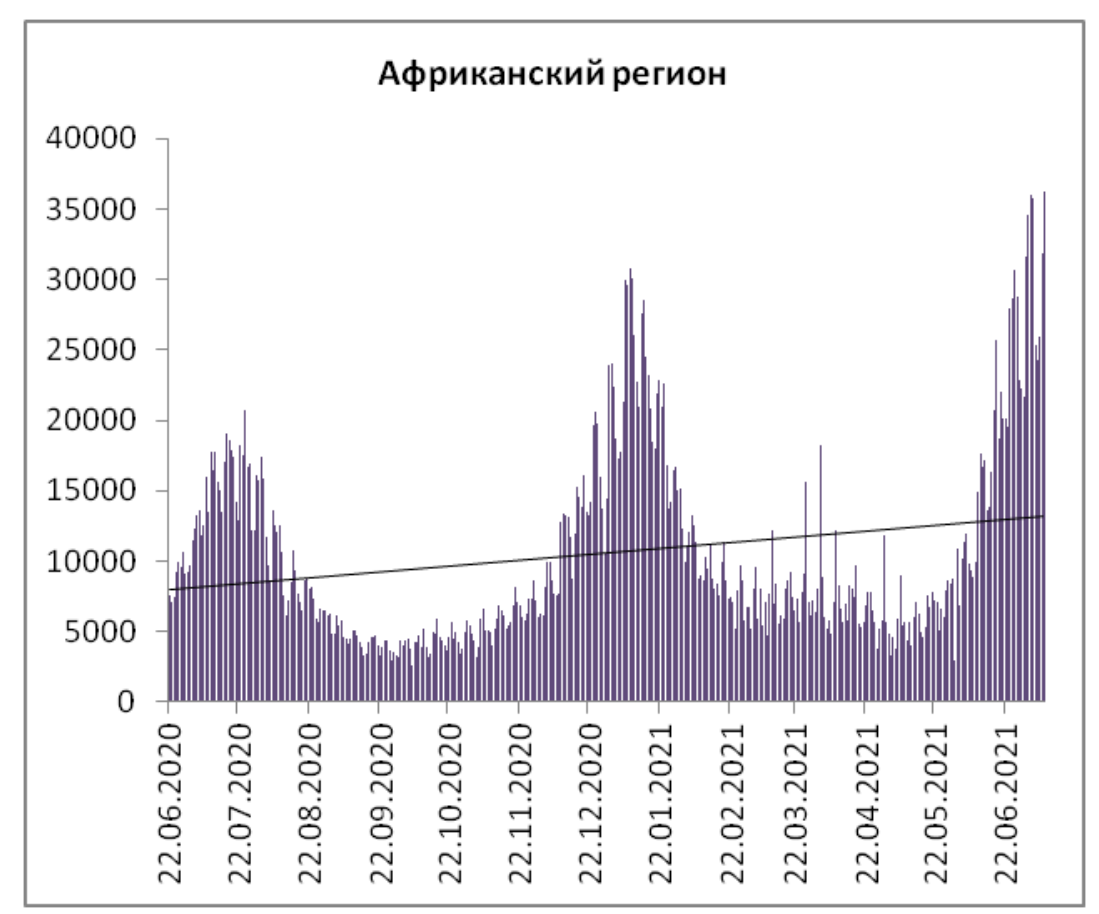

Рисунок 21 - Динамика ежедневного прироста новых случаев в Африканском регионе

В 24 из 48 стран Африканского региона зарегистрирован рост числа новых случаев. Максимальное увеличение еженедельного прироста новых случаев по сравнению с предшествующей неделей демонстрируют Эсватини, Сенегал и Мозамбик (таблица 9). 
Таблица 9 - Страны с максимальным увеличением количества случаев, зарегистрированных за неделю (при сравнении недели с 26 июня по 2 июля и недели 3 по 9 июля).

\begin{tabular}{|c|c|c|c|c|c|}
\hline \multirow{2}{*}{ Страна } & \multicolumn{4}{|c|}{ Зарегистрировано } & \multirow{2}{*}{ Увеличение } \\
\cline { 2 - 5 } & с 26 июня по 2 июля & \multicolumn{2}{|c|}{ с 3 по 9 июля } & \\
\cline { 1 - 5 } & абс. число & на 1 млн & абс. число & на 1 млн & \\
\hline Эсватини & 137 & 119,3 & 578 & 503,5 & \multirow{2}{*}{ в 4,2 раза } \\
\hline Сенегал & 591 & 30,7 & 1522 & 79,0 & в 2,5 раза \\
\hline Мозамбик & 3553 & 117,0 & 7717 & 254,1 & в 2,2 раза \\
\hline
\end{tabular}

На ЮАР приходится 82,5\% от всех выявленных за неделю случаев в Африканском регионе в период с 3 по 9 июля (рисунок 22).

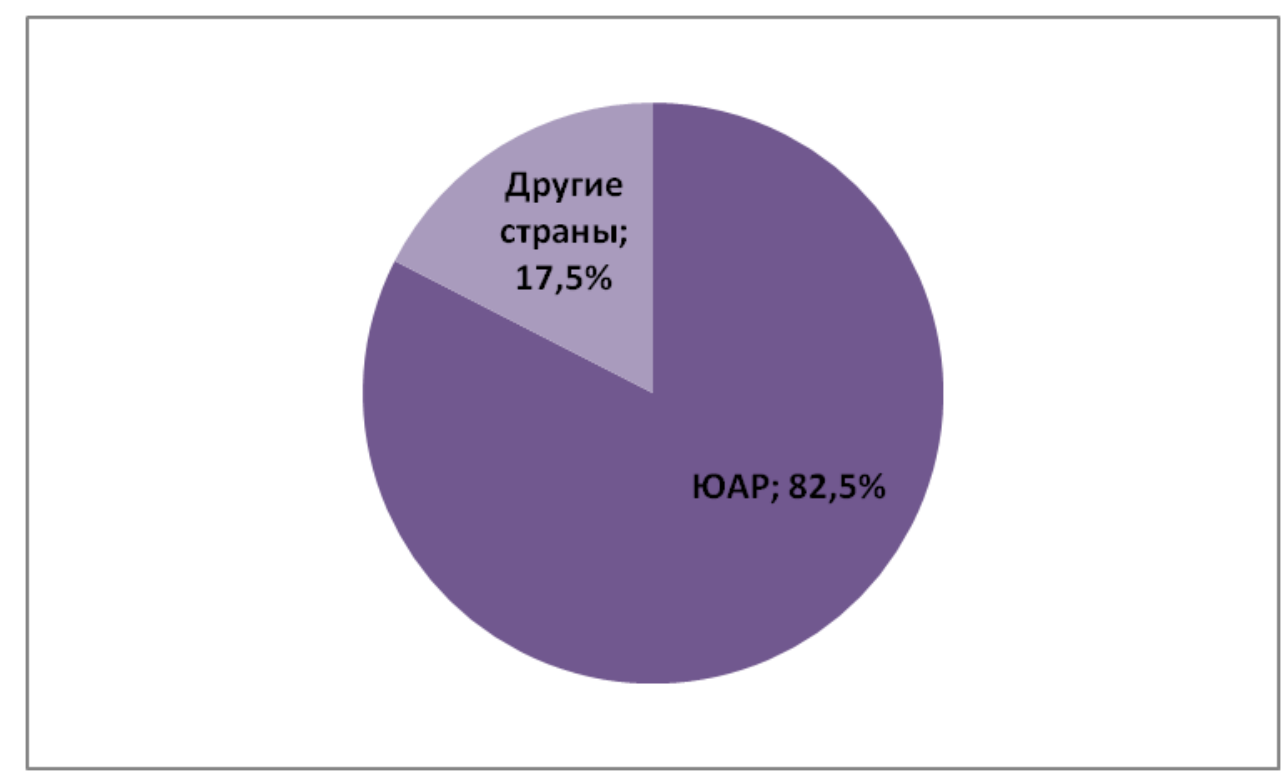

Рисунок 22 - Удельный вес ЮАР в структуре случаев, зарегистрированных за отчетную неделю в Африканском регионе

Наибольшее число заболевших на 1 млн населения за последнюю неделю зарегистрировано на Сейшелах (11225), в Намибии (3925) и ЮАР (2542). 
Наибольшее число летальных исходов на 1 млн населения за последнюю неделю зарегистрировано в Намибии (102), на Сейшелах (61) и в ЮАР (45).

Резкий рост уровня заболеваемости отмечается в Мозамбике. За последнюю неделю зарегистрировано в 2,2 раза больше случаев, чем неделей ранее. 8 июля директор по исследованиям Национального института здравоохранения (INS) страны заявил, что в Мозамбике началась третья волна заболеваемости. Он отметил, что Мозамбик сейчас столкнулся с дельта-вариантом коронавируса.

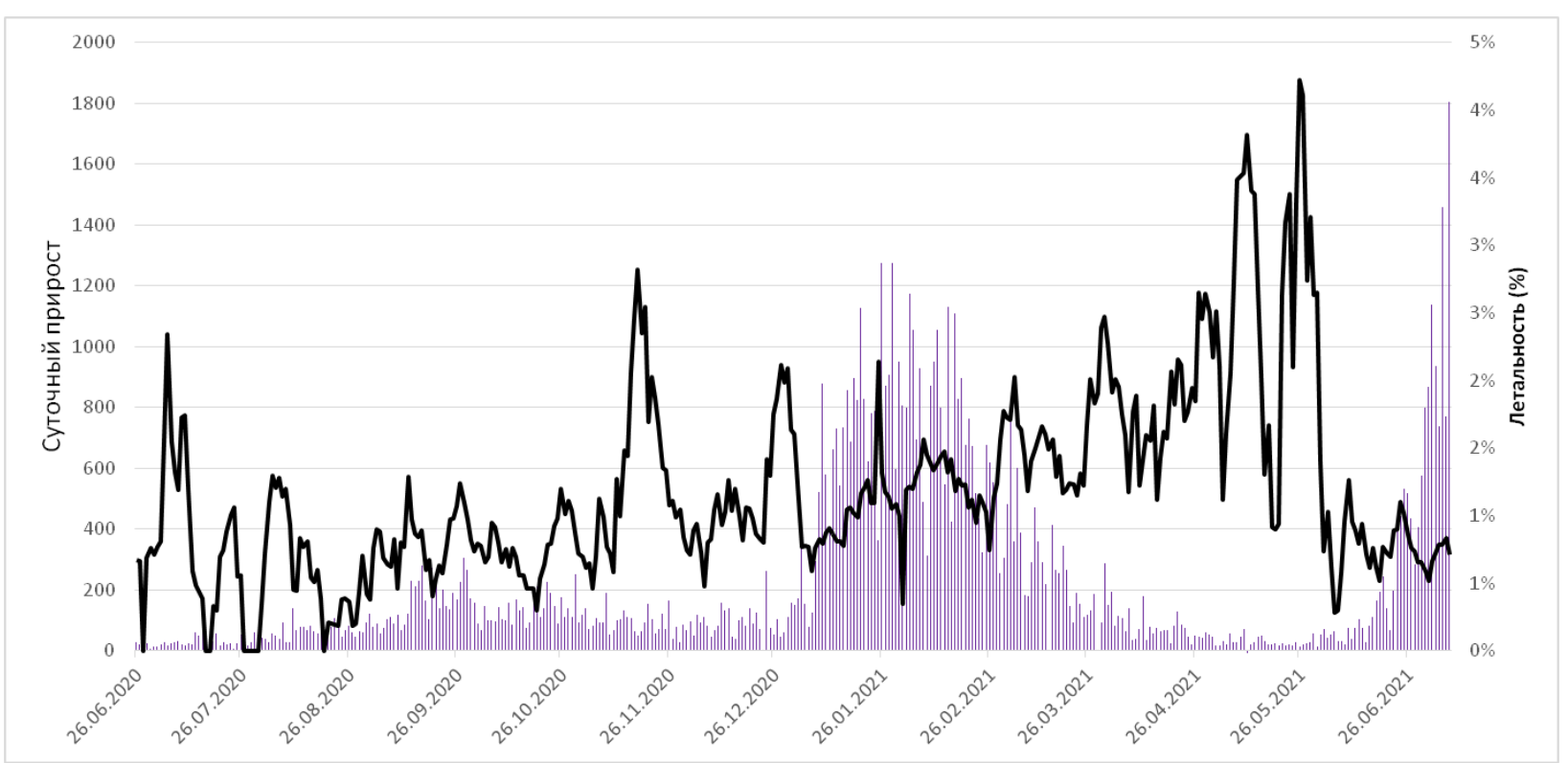

Рисунок 23 - Динамика ежесуточного прироста новых случаев заболевания и летальности в Мозамбике (как отношения средних показателей прироста смертей и случаев за 7-дневный период) 